\title{
Specific Targeting Highly Conserved Residues in the HIV-1 Reverse Transcriptase Primer Grip Region. Design, Synthesis, and Biological Evaluation of Novel, Potent, and Broad Spectrum NNRTIs with Antiviral Activity
}

\begin{abstract}
Caterina Fattorusso, ${ }^{\|, \perp}$ Sandra Gemma, ${ }^{\S, \perp}$ Stefania Butini, ${ }^{\S, \perp}$ Paul Huleatt $, \$, \perp$ Bruno Catalanotti, ${ }^{\|, \perp}$ Marco Persico $, 1, \perp$ Meri De Angelis, ${ }^{\S, \perp}$ Isabella Fiorini, ${ }^{\S, \perp}$ Vito Nacci, ${ }^{\S, \perp}$ Anna Ramunno, ${ }^{\S}$ Manuela Rodriquez, ${ }^{\S}$ Giovanni Greco, $, \perp, \perp$ Ettore Novellino, $, \perp, \perp$ Alberto Bergamini, ${ }^{\dagger}$ Stefano Marini, ${ }^{\dagger}$ Massimo Coletta, ${ }^{\dagger}$ Giovanni Maga ${ }^{\ddagger \perp}$ Silvio Spadari, ${ }^{\ddagger \perp}$ and Giuseppe Campiani ${ }^{\S, \perp, *}$

Dipartimento Farmaco Chimico Tecnologico, via Aldo Moro, European Research Centre for Drug Discovery and Development, Universita' degli Studi di Siena, 53100 Siena, Italy, Dipartimento di Chimica delle Sostanze Naturali e Dipartimento di Chimica Farmaceutica e Tossicologica, Universita' di Napoli "Federico II", via D. Montesano 49, 80131 Napoli, Italy, Dipartimento di Sanita' Pubblica e Biologia Cellulare (DSP\&BC), Universita' degli Studi di Roma "Tor Vergata”, via Tor Vergata 135, 00133 Roma, Italy, Dipartimento di Medicina Sperimentale e Scienze Biochimiche (DMS\&SB), Universita' degli Studi di Roma Tor Vergata, via Tor Vergata 135, 00133 Roma, Italy, and Istituto di Genetica Molecolare (IGM) - CNR, via Abbiategrasso 207, 27100 Pavia, Italy
\end{abstract}

Received March 21, 2005

Pyrrolobenzoxazepinones (PBOs) represent a new class of human immunodeficiency virus type 1 (HIV-1) nonnucleoside reverse transcriptase (RT) inhibitors (NNRTIs) whose prototype is $\mathbf{5}$. Molecular modeling studies based on the X-ray structures of HIV-1 RT prompted the synthesis of novel analogues which were tested as anti-HIV agents. The PBO derivatives specifically designed to target the highly conserved amino acid residues within the $\beta 12-\beta 13$ hairpin, namely primer grip, proved to be very potent against the most common mutant enzymes, including the highly resistant K103N mutant strain. Structure-activity relationships (SARs) are discussed in terms of a possible interaction with the RT binding site, depending on the nature of the substituents at C-6. Among the pyrrolobenzoxazepines investigated, 15c appeared to be the most promising NNRTI of the series characterized by potent antiviral activity, broad spectrum, and low cytotoxicity. 15c showed synergistic antiviral activity with AZT.

\section{Introduction}

Nonnucleoside reverse transcriptase inhibitors (NNRTIs) are allosteric and noncompetitive modulators of RT, one of the key enzymes in the life cycle of HIV$1 .^{1,2}$ Because of their generally good tolerability and low toxicity, these drugs are essential components of highly active antiretroviral therapy (HAART) in conjunction with nucleoside reverse transcriptase inhibitors (NRTI) and/or protease inhibitors (PI). ${ }^{3}$ The multidrug therapy provides a substantial delay in disease progression compared to monotherapy or dual therapy, allowing significant immune system function restoration and retarding the emergence of resistant viral strains. ${ }^{3,4}$ Clinical trials have shown that NNRTIs often act synergistically with NRTI (such as AZT 1, Chart 1), allowing simplified administration schedules with improvement in patient's adherence to treatment, crucial to preventing suboptimal dosages.

So-called "first generation" NNRTI drugs, such as nevirapine $\mathbf{2}$ and delavirdine $\mathbf{3}$ (Chart 1), are generally very susceptible to the effects of a single critical amino acid change in the NNRTI binding pocket. ${ }^{5,6}$ In contrast,

* To whom correspondence should be addressed. Tel. 0039-0577234172, fax 0039-0577-234333, e-mail:campiani@unisi.it.

$\S$ Universita' degli Studi di Siena.

$\perp$ European Research Centre for Drug Discovery and Development.

" Universita' degli Studi di Napoli "Federico II".

\$ Istituto di Genetica Molecolare, Pavia.

$\dagger$ Universita’ di Roma Tor Vergata.
Chart 1

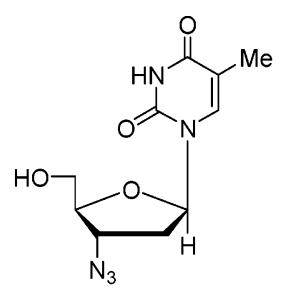

1, AZT

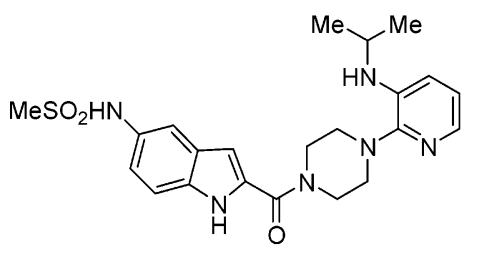

3, Delavirdine

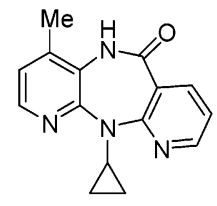

2, Nevirapine<smiles>C[C@]1(C#CC2CC2)OC(=O)Nc2ccc(Cl)cc21</smiles>

4, Efavirenz<smiles>CCC1(c2ccccc2)Oc2ccccc2-n2cccc2C1=O</smiles>

5, $\mathrm{PBO}$

the more recent "second generation" NNRTIs (e.g. efavirenz 4, Chart 1) are characterized by a more 
favorable profile of resilience to common resistance mutations. ${ }^{7}$ However, the possible development of resistance (especially cross-resistance) to such compounds, with reduction of therapeutic options in the case of unsuccessful regimens, makes the continuous development of new, potent, broad-spectrum NNRTI antiviral agents necessary.

In a previous paper $8 \mathrm{a}$ we reported a series of pyrrolobenzoxazepinone (PBOs) derivatives as novel NNRTIs. Some of these analogues were found to be active toward wild type and mutated HIV-1 RT enzymes, to act synergistically in combination with AZT, and to achieve high concentrations in the brain..$^{9 a, b}$ Herein we report a new series of analogues characterized by high potency and a broadened spectrum of activity.

We focused our efforts on the identification of those structural requirements responsible for high activity toward a wide range of HIV-1 variants in order to develop potential drugs with improved resistance profiles for chronic use in anti-HIV combination therapy. The discovery that some highly conserved amino acid residues in the NNRTI binding pocket are essential for viral replication provided useful information for the rational design of new anti-HIV drugs. Indeed, improved binding at these amino acids could result in the development of novel NNRTIs not sensitive to the common enzyme mutations, which mainly occur at residues Y181, Y188, and K103. Four residues were identified as highly conserved among those lining the NNRTI binding site: F227, W229, L234, and Y318. With the exception of Y318, all the other residues are part of the $\beta 12-\beta 13$ hairpin (F227-H235), namely primer grip, responsible for maintaining the primer terminus in the appropriate orientation for nucleophilic attack on an incoming dNTP. ${ }^{10}$ The crucial role of the primer grip was recently investigated and it was found that several mutations in this region significantly compromise RNAand DNA-dependent DNA polymerase activities. ${ }^{11 a-d}$ In particular, mutations of W229, including the conservative mutations W229F and W229Y, reduced RT activity to $<2 \%$. ${ }^{11 c}$ Moreover, mutation of the key W229 has never been observed in combination with other mutations, indicating that compensatory mutations to restore RT activity of the W229 mutated enzyme will not easily occur. ${ }^{11 c, d}$ Hence, W229 has been proposed to be vital for correct protein folding and/or for stabilizing the complex between RT and the template-primer. ${ }^{11 b, c}$ This proposal is supported by the experimentally determined structures of HIV-1 RT in complex with a doublestranded DNA template- primer ${ }^{12}$ (binary complex) and of the covalently trapped catalytic complex of HIV-1 $\mathrm{RT}^{13}$ (mimicking the ternary complex). HIV-1 RT X-ray structures prove that the movement of the primer grip region (W229) with respect to Y181 and Y188 (located, together with the catalytic residues D185 and D186, in the $\beta 9-\beta 10$ hairpin) is crucial for enzyme function. On the other hand, the locking of the W229 position represents the molecular basis of NNRTI activity. Accordingly, the design approach discussed herein was mainly based on the hypothesis that targeting the conservative residue W229 for more extensive interaction with an inhibitor may lead to the discovery of potent NNRTIs that are less sensitive to resistance mutations.

\section{Scheme $1^{a}$}

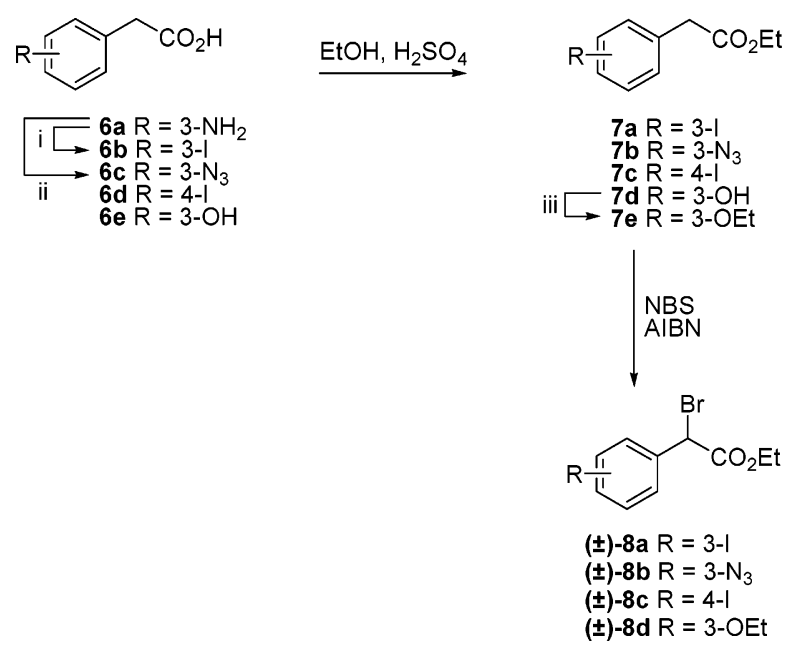

$a$ (i) $\mathrm{NaNO}_{2}, \mathrm{H}^{+}, \mathrm{KI}$; (ii) $\mathrm{NaNO}_{2}, \mathrm{H}^{+}, \mathrm{NaN}_{3}$; (iii) $t$-BuONa, EtI.

On this basis, we first designed a new set of compounds (13d-i and 21a,b) to extend the scope of previous SAR studies and to evaluate the effect (steric and/or electronic) on antiviral activity of substituents on the C-6 phenyl ring. Subsequently, from SAR and docking results, and on the basis of a thorough investigation of the topology of wild type (wt) and mutated RTs (free and NNRTI bound), also taking into consideration the different functional states of the enzyme, we designed novel NNRTIs specifically aimed to bind the highly conserved residue W229 (15a-1).

This strategy led to the identification of novel antiviral agents with a promising pharmacological profile. Herein the molecular modeling approach, the synthesis, and the biological investigation are discussed, and a synergistic study is also included.

\section{Chemistry}

The new PBOs derivatives were synthesized as shown in Schemes 1-4.

Following a previously reported procedure ${ }^{8 a}$ the bromoesters $8 \mathbf{a}-\mathbf{d}$ were prepared starting from the corresponding ethyl phenylacetates $\mathbf{7 a}-\mathbf{c}, \mathbf{e}$ (Scheme 1). Starting from 3-aminophenylacetic acid $\mathbf{6 a}$, through a Sandmayer-type reaction, 3-iodophenylacetic acid $\mathbf{6 b}$ and the azido derivative $6 \mathbf{c}$ were synthesized. Iodophenylacetic acid ethyl esters and their corresponding bromo derivatives ${ }^{8 b, c}$ were synthesized by the method reported in Scheme 1.8a Esterification of 6 e afforded 3 -hydroxyphenylacetic acid $\mathbf{7} \mathbf{d}^{8 \mathrm{~d}}$ which was converted to 3-ethoxyphenyl acetate 7e. The analogous intermediate $( \pm)$ - $\alpha$-bromo-(3-chlorophenyl)acetic acid ethyl ester was prepared according to reference $8 \mathrm{e}$.

Scheme 2 describes the synthesis of compounds ( \pm )13d-i. O-Alkylation of 1-(2-hydroxyphenyl)pyrrole $\mathbf{9}^{8 \mathrm{a}}$ with the suitable ethyl $\alpha$-bromophenylacetate $\mathbf{8}$ afforded esters $( \pm)-\mathbf{1 0 a}-\mathbf{e}$. Then the ethyl substituent was introduced using iodoethane in the presence of lithium diisopropylamide to give esters $( \pm)-\mathbf{1 1 a}-\mathbf{e}$. After saponification of the ethyl ester group (affording $( \pm)-\mathbf{1 2 a}-$ e), and intramolecular Friedel-Crafts cyclization compounds $( \pm)-\mathbf{1 3 d}-\mathbf{g}, \mathbf{i}$ were obtained. Reduction of the azido group of $( \pm)$-13f led to the corresponding amine $( \pm)-\mathbf{1 3 h}$ in good yield. 


\section{Scheme 2}<smiles>Oc1ccccc1-n1cccc1</smiles>

9
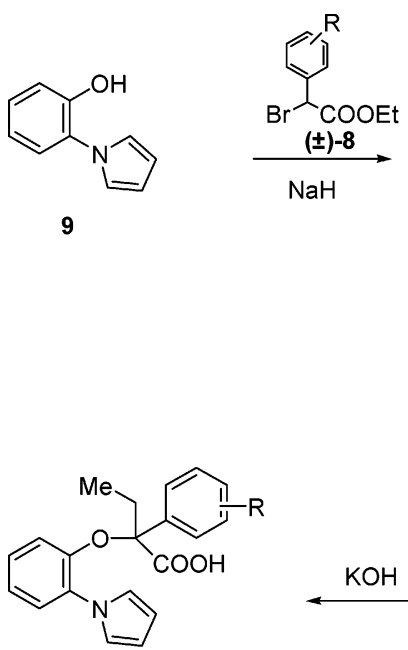

(士)-12a-e

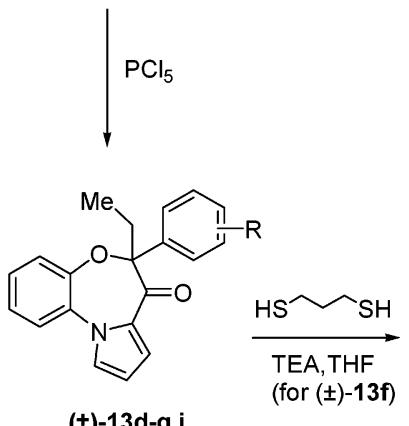

(士)-13d-g,i

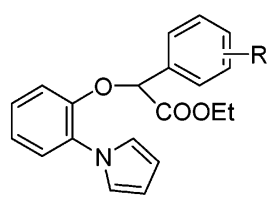

(士)-10a-e
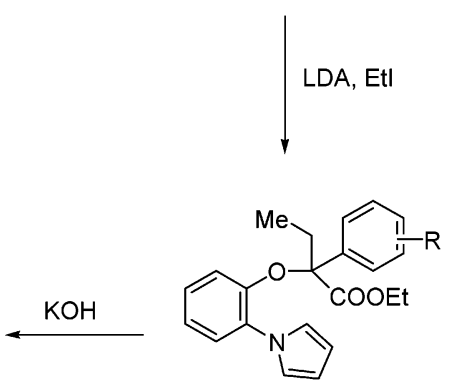

(士)-11a-e

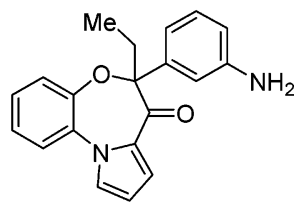

$( \pm)-13 h$
Bromination of ketones $( \pm)-\mathbf{1 3} \mathbf{b}, \mathbf{j}^{8 a, 14}$ (Scheme 3 ) with $N$-bromosuccinimide (NBS) and a catalytic amount of azobisisobutyronitrile (AIBN), led to derivatives $( \pm$ )$\mathbf{1 4 a}, \mathbf{b}$ and these key intermediates were converted to the desired compounds $( \pm)-\mathbf{1 5 a}-\mathbf{l}$. While $( \pm)-\mathbf{1 5 a}-\mathbf{j}$ were synthesized using $( \pm)-\mathbf{1 4 a}, \mathbf{b}$ as alkylating agents compound $( \pm)-\mathbf{1 5 k}$ was obtained by means of a Wittigtype reaction using benzaldehyde. Subsequent catalytic hydrogenation provided $( \pm)-\mathbf{1 5 1}$. The synthesis of benzazepines $( \pm)-\mathbf{2 1 a}, \mathbf{b}$ is reported in Scheme 4 . The 3-chlorophenyl ester intermediate $\mathbf{1 7}$ was obtained by Wadsworth-Emmons olefination, starting from methyl ( \pm -- $\alpha$-bromo(3-chlorophenyl)acetate and aldehyde $\mathbf{1 6} .15 \mathrm{~b}$ The ester 17 was saponified to give the corresponding acid 18, which was cyclized to the enone 19. After hydrogenation, the ketone $( \pm)-20 b$ was obtained. Alkylation of $( \pm)-20 b$ and its unsubstituted counterpart $( \pm)$ $\mathbf{2 0 a}^{15 b}$ gave the desired benzazepinones $( \pm)-\mathbf{2 1 a}, \mathbf{b}$.

\section{Biological Results}

Enzymatic Assays. In Vitro Structure-Activity Relationships and Molecular Modeling Studies. In previous work ${ }^{8 a}$ we investigated the PBO skeleton by making specific substitutions on the pendant phenyl ring at C-6 (Table 1, 13a-c). The meta-substituted PBO 13c was identified as a valuable lead to develop novel anti-HIV agents, despite its inactivity against the common Y181I and Y188L mutants. To define how the physical-chemical properties of the substituents at C-6 could influence the inhibition of HIV-1 RTs (wild type and mutants), we improved the SARs of the PBO series of antivirals, by designing and synthesizing the ana-

\section{Scheme 3}
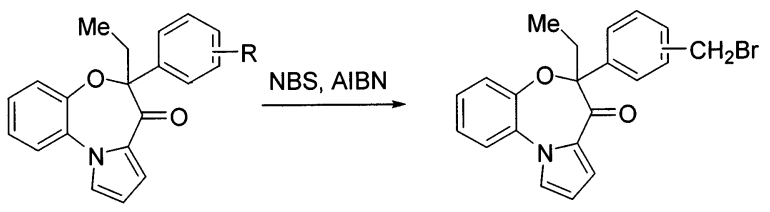

(士)-13b, R = 3-Me (士)-13j, $R=4-M e$

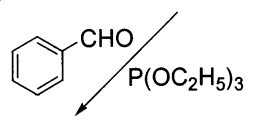

(士)-14a, 4- $\mathrm{CH}_{2} \mathrm{Br}$ (士)-14b, 3- $\mathrm{CH}_{2} \mathrm{Br}$ $\mathrm{ArOH}$ or $\mathrm{ArNH}_{2}$<smiles>CCC1(c2ccc(/C=C/c3ccccc3)cc2)Oc2ccccc2-n2cccc2C1=O</smiles>

(士)-15k

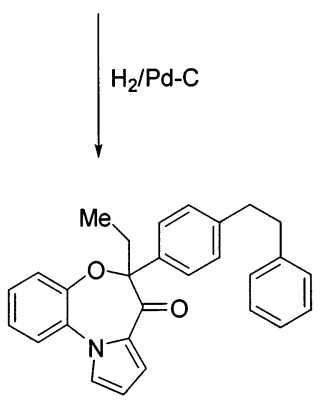

( \pm -15I<smiles>CCC1(C2=CC=CC(Cc3ccccc3)C2)Oc2ccccc2-n2cccc2C1=O</smiles>

$( \pm)-15 a-j$ ogues $\mathbf{1 3 d}-\mathbf{i}$ and $\mathbf{1 5 a}-\mathbf{l}$ (Table 1). The newly described PBO analogues 13 and $\mathbf{1 5}$ were tested in an in vitro HIV-1 RTwt assay to evaluate their potential as antiHIV drugs. The results are summarized in Table 2 as $K_{\mathrm{i}}$ values. In addition, to evaluate the potential of these antienzymatic derivatives as novel broad spectrum antiviral agents, all active compounds were also tested on a panel of RT mutants including L100I, Y181I, V106A, and K103N, a mutant associated with resistance to pyridones and nevirapine. Y188L, a mutation of RT that appears in patients treated with both nevirapine and AZT, was also included. The first question addressed was whether, by expanding the SAR studies of the PBO class of antiviral agents closely related to $\mathbf{5}$, the antiviral activity and the spectrum of antienzymatic activity could be improved over previously described PBOs. SAR studies were conducted by appropriately varying the substituents on the C-6 phenyl ring.

As illustrated in Table 2, replacement of the meta methoxy group of $13 \mathbf{c}$ by a chlorine atom $(\mathbf{1 3 d})$, resulted in a 2-fold increase of potency $\left(K_{\mathrm{i}}=0.036 \mu \mathrm{M}\right)$ toward the wild-type HIV-1 RT (RTwt), and broadened the spectrum of activity against Y181I and Y188L mutants (13c, $K_{\mathrm{iY} 181 \mathrm{I}}$ and $K_{\mathrm{iY} 188 \mathrm{~L}}>10 \mu \mathrm{M}$ vs. $13 d, \mathrm{Ki}_{\mathrm{Y} 181 \mathrm{I}}=0.8$ $\left.\mu \mathrm{M} ; K_{\mathrm{iY} 188 \mathrm{~L}}=0.5 \mu \mathrm{M}\right)$. However, 13d was not able to inhibit the highly resistant K103N mutant.

The substitution of the $m$-chlorine atom of $\mathbf{1 3 d}$ by the larger and less electron-withdrawing iodine atom led to a potent inhibitor of RTwt $\left(\mathbf{1 3 e}, K_{\mathrm{i}}=0.05 \mu \mathrm{M}\right)$ charac- 


\section{Scheme 4}<smiles>O=Cc1ccccc1-n1cccc1</smiles><smiles>COC(=O)c1cccc(Cl)c1</smiles>

$\mathrm{NaH}, \mathrm{THF}$, it $1 \mathrm{~h}$

16

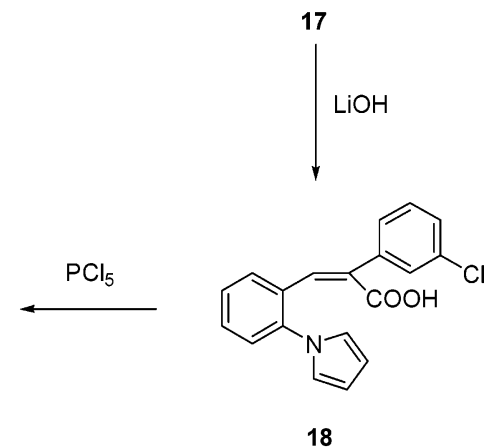

19<smiles>[R]c1cccc(C2Cc3ccccc3-n3cccc3C2=O)c1</smiles>

(士)-20a, R = H (士)-20b, R = Cl
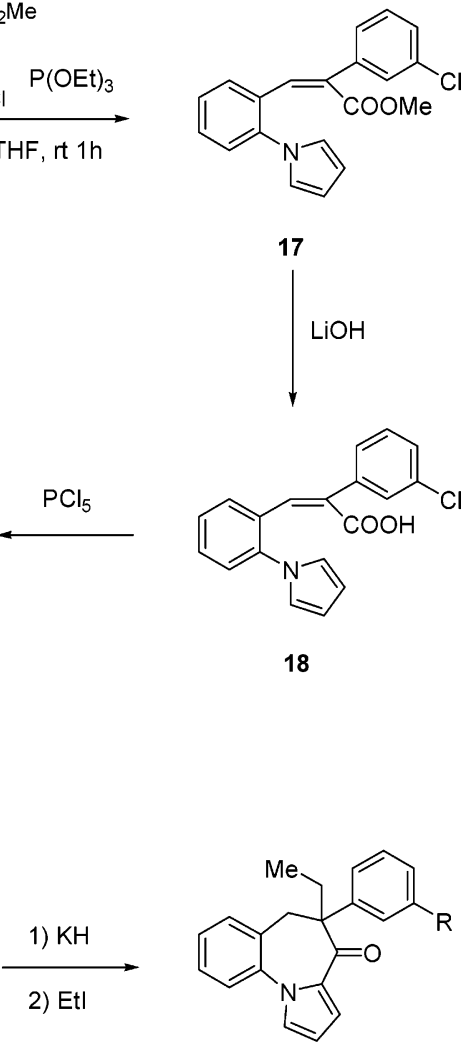

$( \pm)-21 a, R=H$ (士)-21b, $\mathrm{R}=\mathrm{Cl}$ terized by negligible activity against mutated enzymes, with the exception of the V106A mutant $\left(K_{\mathrm{iV} 106 \mathrm{~A}}=0.13\right.$ $\mu \mathrm{M})$. Introduction of the iodine atom at the para position (13i) of the pendant phenyl ring led to an analogue characterized by a weak activity against wt and mutated RTs (Table 2).

On the other hand, the presence of a hydrophilic and electron-donating amino group at the meta position (13h) resulted in a loss of enzymatic activity against mutated strains.

To evaluate the room available in the proximity of the meta position of the C- 6 phenyl ring at the binding site level, compound $\mathbf{1 3} \mathbf{g}$ was synthesized and tested. The bulkier $m$-ethoxy group resulted in a 13 -fold decrease of anti-RTwt activity, while broadening the spectrum of activity against Y181I and Y188L mutants (13g vs 13c). On the other hand, the introduction of the bulky and conformationally constrained azido group (13f) resulted in a complete loss of inhibitory activity against wt and mutated RTs.

We investigated the meta-substituted PBOs' binding mode by docking compounds 13c and 13d into the nonnucleoside binding site (NNBS) of HIV1-RT (PDB code: 1VRT), in order to understand the structural basis of mutant sensitivity, with a view to developing more potent and broader spectrum HIV1-RT nonnucleoside inhibitors. 13c and 13d are two of the most potent broad spectrum PBOs and are characterized by different inhibitory activity against K103N, Y181I, and Y188L RTs. 13c is completely inactive against Y181I and Y188L mutants and 13d is completely inactive against K103N mutant. This thorough molecular modeling study allowed us to clarify the molecular basis of the inhibitory activity of 13c and 13d against HIV-1 RTs, and to develop new analogues bearing key structural features specifically designed to target the highly conserved amino acids in the primer grip region, in particular W229.

In the docking studies $S$-enantiomers of $\mathbf{1 3 c}$ and $\mathbf{1 3 d}$ were used in accordance with our previous results. ${ }^{8 a, 16}$ A flexible docking procedure was applied, including Monte Carlo and Simulated Annealing methods, with the aim of allowing the maximum adaptability of the binding site around the inhibitor (Affinity, Accelrys, San Diego). It must be noted that the docking procedure we used allows the mutual adaptability of the ligand with respect to the binding site, considering both the inhibitor and the protein binding site fully flexible during the entire calculations. Indeed, the X-ray structures of wild type and mutated HIV1-RTs (alone and in complex with various inhibitors ${ }^{17}$ ) evidenced that the hydrophobic pocket constituting the NNBS can vary in dimension and shape, depending on the conformational state of the protein (i.e. free RT, binary complex, ternary complex) and, in the RT/NNRTI structures, on the nature of the bound NNRTI. Moreover, many different binding modes have been reported for different classes of inhibitors, as well as for compounds which have close structural correlation. ${ }^{18}$

Furthermore, to improve the reliability of the docking results, we increased the variance of the starting structures by considering 13c and 13d in both the pseudoaxial and pseudoequatorial pendant phenyl ring conformations, and by performing two docking calculations for each of the four starting complexes using two different energy check criteria for the selection of acceptable structures (see Experimental Section). Docking solutions were ranked by evaluating the complex energy and the ligand-enzyme interaction energy. The results are reported in Figure $1 \mathrm{~A}, \mathrm{~B}$. Both $\mathbf{1 3 c}$ and $\mathbf{1 3 d}$ bind the NNBS with the pendant phenyl ring at C-6 in an axial position, but they adopt different binding modes (Figure 1A, 13c and Figure 1B, 13d).

13c binds NNBS orienting the ethyl substituent in close proximity to V106, L234, and F227 establishing van der Waals contacts with these residues. The $m$ methoxyphenyl ring is positioned within the aromatic cleft identified by Y181 and Y188, and also interacts with W229 through favorable polarized $\pi-\pi$ contacts. The benzo-fused ring is oriented between V179 and L100 while the pyrrole moiety establishes a polarized, edge-to-face, $\pi-\pi$ interaction with another highly conserved residue, Y318. Moreover, the carbonyl oxygen of 13c is H-bonded through a bridged water molecule with L234 carbonyl oxygen.

13d is oriented differently: the C-6 ethyl group is embedded within the hydrophobic pocket defined by V106, V179, I180, and V189 (as is the cyclopropyl moiety of nevirapine (PDB code: 1VRT)), while the pyrrole ring interacts with Y181 through a parallel displaced aromatic $\pi-\pi$ interaction. The benzo-fused ring of $\mathbf{1 3 d}$ is oriented in a fashion similar to the $m$-methoxyphenyl ring of 13c, thereby establishing a polarized $\pi-\pi$ stacking interaction with Y188 and a T-shaped $\pi-\pi$ interaction with W229. The $m$-Cl-substituted pendant phenyl ring is accommodated in the hydrophobic pocket 
Table 1. Physical and Chemical Data for Compounds $( \pm)-\mathbf{1 3},( \pm)-\mathbf{1 4},( \pm)-\mathbf{1 5}, \mathbf{1 7}, \mathbf{1 8}, \mathbf{1 9},( \pm)-\mathbf{2 0 b}$, and $( \pm)-\mathbf{2 1}$

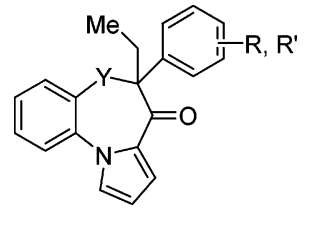

13a-i, 15a-I, 21a,b

\begin{tabular}{|c|c|c|c|c|c|c|c|}
\hline compd & $\mathrm{Y}$ & $\mathrm{R}$ & $\mathrm{R}^{\prime}$ & $\%$ yield $^{a}$ & $\mathrm{mp}\left({ }^{\circ} \mathrm{C}\right)$ & formula & analysis $^{b}$ \\
\hline$( \pm) \mathbf{1 3} \mathbf{a}^{c}$ & $\mathrm{O}$ & & & - & - & - & - \\
\hline$( \pm)-\mathbf{1 3} \mathbf{b}^{c}$ & $\mathrm{O}$ & $3-\mathrm{CH}_{3}$ & & - & - & - & - \\
\hline$( \pm)-13 c^{c}$ & $\mathrm{O}$ & $3-\mathrm{OCH}_{3}$ & & - & - & - & - \\
\hline$( \pm)-\mathbf{1 3 d}$ & $\mathrm{O}$ & $3-\mathrm{Cl}$ & & 30 & $104-105$ & $\mathrm{C}_{20} \mathrm{H}_{16} \mathrm{ClNO}_{2}$ & $\mathrm{C}, \mathrm{H}, \mathrm{N}$ \\
\hline$( \pm)-13 e$ & $\mathrm{O}$ & 3-I & & 40 & $116-118$ & $\mathrm{C}_{20} \mathrm{H}_{16} \mathrm{INO}_{2}$ & $\mathrm{C}, \mathrm{H}, \mathrm{N}$ \\
\hline$( \pm)-\mathbf{1 3 f}$ & $\mathrm{O}$ & $3-\mathrm{N}_{3}$ & & 60 & $107-108$ & $\mathrm{C}_{20} \mathrm{H}_{16} \mathrm{~N}_{4} \mathrm{O}_{2}$ & $\mathrm{C}, \mathrm{H}, \mathrm{N}$ \\
\hline$( \pm)-\mathbf{1 3 g}$ & $\mathrm{O}$ & 3 -OEt & & 60 & $102-103$ & $\mathrm{C}_{22} \mathrm{H}_{21} \mathrm{NO}_{3}$ & $\mathrm{C}, \mathrm{H}, \mathrm{N}$ \\
\hline$( \pm)-\mathbf{1 3 h}$ & $\mathrm{O}$ & $3-\mathrm{NH}_{2}$ & & 50 & $105-106$ & $\mathrm{C}_{20} \mathrm{H}_{18} \mathrm{~N}_{2} \mathrm{O}_{2}$ & $\mathrm{C}, \mathrm{H}, \mathrm{N}$ \\
\hline$( \pm)-\mathbf{1 3 i}$ & $\mathrm{O}$ & $4-\mathrm{I}$ & & 70 & $114-116$ & $\mathrm{C}_{20} \mathrm{H}_{16} \mathrm{INO}_{2}$ & $\mathrm{C}, \mathrm{H}, \mathrm{N}$ \\
\hline$( \pm)-\mathbf{1 3} \mathbf{j}^{c}$ & $\mathrm{O}$ & $4-\mathrm{CH}_{3}$ & & - & - & - & - \\
\hline$( \pm)-\mathbf{1 4 a}$ & $\mathrm{O}$ & 4- $\mathrm{CH}_{2} \mathrm{Br}$ & & 64 & $111-113$ & $\mathrm{C}_{21} \mathrm{H}_{18} \mathrm{BrNO}_{2}$ & $\mathrm{C}, \mathrm{H}, \mathrm{N}$ \\
\hline$( \pm)-\mathbf{1 4 b}$ & $\mathrm{O}$ & $3-\mathrm{CH}_{2} \mathrm{Br}$ & & 90 & $124-125$ & $\mathrm{C}_{21} \mathrm{H}_{18} \mathrm{BrNO}_{2}$ & $\mathrm{C}, \mathrm{H}, \mathrm{N}$ \\
\hline$( \pm)-\mathbf{1 5 a}$ & $\mathrm{O}$ & & $3-\mathrm{CH}_{2} \mathrm{OC}_{6} \mathrm{H}_{5}$ & 50 & - & $\mathrm{C}_{27} \mathrm{H}_{23} \mathrm{NO}_{3}$ & $\mathrm{C}, \mathrm{H}, \mathrm{N}$ \\
\hline$( \pm)-\mathbf{1 5 b}$ & $\mathrm{O}$ & & 4- $\mathrm{CH}_{2}$ Oisopentenyl & 47 & - & $\mathrm{C}_{26} \mathrm{H}_{27} \mathrm{NO}_{3}$ & $\mathrm{C}, \mathrm{H}, \mathrm{N}$ \\
\hline$( \pm)-15 c$ & $\mathrm{O}$ & & $4-\mathrm{CH}_{2} \mathrm{OC}_{6} \mathrm{H}_{5}$ & 64 & $\overline{1} 51-152$ & $\mathrm{C}_{27} \mathrm{H}_{23} \mathrm{NO}_{3}$ & $\mathrm{C}, \mathrm{H}, \mathrm{N}$ \\
\hline$( \pm)-\mathbf{1 5 d}$ & $\mathrm{O}$ & & $4-\mathrm{CH}_{2} \mathrm{NH}-\mathrm{C}_{6} \mathrm{H}_{5}$ & 53 & $171-172$ & $\mathrm{C}_{27} \mathrm{H}_{24} \mathrm{~N}_{2} \mathrm{O}_{2}$ & $\mathrm{C}, \mathrm{H}, \mathrm{N}$ \\
\hline$( \pm)-15 e$ & $\mathrm{O}$ & & $4-\mathrm{CH}_{2} \mathrm{O}\left(2-\mathrm{ClC}_{6} \mathrm{H}_{5}\right)$ & 61 & $142-143$ & $\mathrm{C}_{27} \mathrm{H}_{22} \mathrm{ClNO}_{3}$ & $\mathrm{C}, \mathrm{H}, \mathrm{N}$ \\
\hline$( \pm)-\mathbf{1 5 f}$ & $\mathrm{O}$ & & $4-\mathrm{CH}_{2} \mathrm{O}\left(3-\mathrm{ClC}_{6} \mathrm{H}_{5}\right)$ & 52 & & $\mathrm{C}_{27} \mathrm{H}_{22} \mathrm{ClNO}_{3}$ & $\mathrm{C}, \mathrm{H}, \mathrm{N}$ \\
\hline$( \pm)-15 g$ & $\mathrm{O}$ & & $4-\mathrm{CH}_{2} \mathrm{O}\left(2-\mathrm{COCH}_{3}\right) \mathrm{C}_{6} \mathrm{H}_{5}$ & 76 & $125-126$ & $\mathrm{C}_{29} \mathrm{H}_{25} \mathrm{NO}_{4}$ & $\mathrm{C}, \mathrm{H}, \mathrm{N}$ \\
\hline$( \pm)-\mathbf{1 5 h}$ & $\mathrm{O}$ & & $4-\mathrm{CH}_{2} \mathrm{NH}\left(3-\mathrm{FC}_{6} \mathrm{H}_{5}\right)$ & 58 & $144-145$ & $\mathrm{C}_{27} \mathrm{H}_{23} \mathrm{FN}_{2} \mathrm{O}_{2}$ & $\mathrm{C}, \mathrm{H}, \mathrm{N}$ \\
\hline$( \pm)-\mathbf{1 5 i}$ & $\mathrm{O}$ & & 4- $\mathrm{CH}_{2} \mathrm{O}$ (3-pyridyl) & 67 & $103-105$ & $\mathrm{C}_{26} \mathrm{H}_{22} \mathrm{~N}_{2} \mathrm{O}_{3}$ & $\mathrm{C}, \mathrm{H}, \mathrm{N}$ \\
\hline$( \pm)-\mathbf{1 5 j}$ & $\mathrm{O}$ & & $4-\mathrm{CH}_{2}$-[3-(2-imino-2,3-dihydro)thiazolyl] & 83 & & $\mathrm{C}_{24} \mathrm{H}_{21} \mathrm{~N}_{3} \mathrm{O}_{2} \mathrm{~S}$ & $\mathrm{C}, \mathrm{H}, \mathrm{N}$ \\
\hline$( \pm)-\mathbf{1 5 k}$ & $\mathrm{O}$ & & & 78 & $\overline{1} 49-151$ & $\mathrm{C}_{28} \mathrm{H}_{23} \mathrm{NO}_{2}$ & $\mathrm{C}, \mathrm{H}, \mathrm{N}$ \\
\hline$( \pm)-\mathbf{1 5 l}$ & $\mathrm{O}$ & & & 88 & $129-130$ & $\mathrm{C}_{28} \mathrm{H}_{25} \mathrm{NO}_{2}$ & $\mathrm{C}, \mathrm{H}, \mathrm{N}$ \\
\hline $\mathbf{1 6}^{d}$ & & & & - & - & - & \\
\hline 17 & & & & 57 & _ & $\mathrm{C}_{20} \mathrm{H}_{16} \mathrm{ClNO}_{2}$ & $\mathrm{C}, \mathrm{H}, \mathrm{N}$ \\
\hline 18 & & & & 54 & - & $\mathrm{C}_{19} \mathrm{H}_{14} \mathrm{ClNO}_{2}$ & $\mathrm{C}, \mathrm{H}, \mathrm{N}$ \\
\hline 19 & & & & 49 & $\overline{1} 02-104$ & $\mathrm{C}_{19} \mathrm{H}_{13} \mathrm{ClNO}$ & $\mathrm{C}, \mathrm{H}, \mathrm{N}$ \\
\hline$( \pm)-\mathbf{2 0 a} \mathbf{a}^{d}$ & & $\mathrm{H}$ & & - & - & - & - \\
\hline$( \pm)-\mathbf{2 0 b}$ & & $\mathrm{Cl}$ & & 23 & & $\mathrm{C}_{19} \mathrm{H}_{14} \mathrm{ClNO}$ & $\mathrm{C}, \mathrm{H}, \mathrm{N}$ \\
\hline$( \pm)-21 \mathbf{a}$ & $\mathrm{CH}$ & $\mathrm{H}$ & & 32 & $\overline{1} 34-135$ & $\mathrm{C}_{21} \mathrm{H}_{19} \mathrm{NO}$ & $\mathrm{C}, \mathrm{H}, \mathrm{N}$ \\
\hline$( \pm)-\mathbf{2 1 b}$ & $\mathrm{CH}$ & $\mathrm{Cl}$ & & 24 & $108-110$ & $\mathrm{C}_{21} \mathrm{H}_{18} \mathrm{ClNO}_{2}$ & $\mathrm{C}, \mathrm{H}, \mathrm{N}$ \\
\hline
\end{tabular}

${ }^{a}$ Yields refer to isolated and purified materials. ${ }^{b}$ All the compounds analyzed were within $\pm 0.4 \%$ of the theoretical values. ${ }^{c}$ Reference 8a. ${ }^{d}$ Reference $15 \mathrm{~b}$.

lined with Y318, F227, V106, and L100 (as is the pyrrole ring of 13c). Finally, the carbonyl oxygen of the oxazepinone ring is $\mathrm{H}$-bonded to a network of water molecules which are linked to the side chain of E138 and the carbonyl oxygen of K101. The results obtained for the two analogues represent an example of different binding modes of members of the same structural class of NNRTIs and may account for their different resistance profiles. The different binding modes found for 13c and 13d may be explained by considering the PBO structures and the architecture of NNBS. Indeed, the latter presents two main aromatic clefts characterized by different shape and overall polarization: (i) Y181, Y183, Y188 ( $\beta 9-\beta 10$ hairpin), and W229 ( $\beta 12-\beta 13$ hairpin, primer grip) (Figure 1A, B orange), and (ii) F227 (primer grip) and Y318 ( $\beta 15)$, (Figure 1A, B yellow). Accordingly, the different binding modes found for 13c and 13d likely reflect the differently polarized pendant phenyl rings at $\mathrm{C}-6$ (13c, 3-OMePh; 13d, 3-ClPh), being oriented according to the overall dipole of the binding site. The dipole moments of $\mathbf{1 3 c}$ and $\mathbf{1 3 d}$ were calculated using partial charges obtained by the quantum mechanical method AM1 and visualized as vectors (Decipher, Accelrys, San Diego). Interestingly, the dipole moments of $\mathbf{1 3 c}$ and $\mathbf{1 3 d}$ are similarly oriented with respect to NNBS in the two different binding modes, supporting the docking results obtained (Figure S1 C, D; Supporting Information). A similar molecular dipole orientation was also found when experimentally determined RT structures in complex with other inhibitors, such as nevirapine and CP-94,707 (PDB codes: 1VRT and 1TV6, respectively) (Figure S1 A, B; Supporting Information) were examined. Moreover, it must be noted that the PBO carbonyl oxygen at C-7 can be perfectly accommodated in both binding modes, establishing watermediated hydrogen bonds with the L234 carbonyl oxygen (13c) or with the side chain of E138 and the carbonyl oxygen of K101 (13d) (Figure 1A, B). These results suggest that due to the symmetry of RT NNBS, binding of inhibitors bearing symmetrical aromatic structural features is driven by the orientation of their dipole moment with respect to the overall dipole of $\mathrm{RT}$ NNBS. ${ }^{19}$ Of course, when hindered and/or conformationally constrained substituents are present (i.e. efavirenz), the binding is dominated by other forces such as favorable or unfavorable van der Waals interactions.

The different binding modes found for 13c and 13d may account for their different sensitivity to HIV-1-RT mutants. Most of the known mutations implicated in drug resistance cause conformational changes of the NNBS, determining detrimental effects on the activity of the inhibitor. In particular, the main structural 
Table 2. Inhibition ( $\left.\mathrm{IC}_{50}, \mu \mathrm{mol}\right)$ of HIV-1 wt and HIV-1 Mutant RT Enzymes, Containing the Single Amino Acid Substitutions L100I, K103N, V106A, Y181I, and Y188L

\begin{tabular}{lcccccc}
\hline compd & WT & L100I & K103N & V106A & Y181I & Y188L \\
\hline$( \pm)-\mathbf{1 3 a} \mathbf{a}^{b}$ & 0.19 & 0.75 & 7.7 & 3.9 & $>10$ & $>10$ \\
$( \pm)-\mathbf{1 3 b} \mathbf{b}^{b}$ & 0.07 & 0.1 & 1.1 & 0.25 & 4 & 1.9 \\
$( \pm)-\mathbf{1 3} \mathbf{c}^{b}$ & 0.06 & 0.011 & 0.022 & 0.01 & $>10$ & $>10$ \\
$( \pm)-\mathbf{1 3 d}$ & 0.036 & 0.6 & $\mathrm{NA}$ & 0.2 & 0.8 & 0.5 \\
$( \pm)-\mathbf{1 3 e}$ & 0.05 & $>10$ & $>10$ & 0.13 & $>10$ & $>10$ \\
$( \pm)-\mathbf{1 3 f}$ & $\mathrm{NA}$ & $\mathrm{NT}$ & $\mathrm{NT}$ & $\mathrm{NT}$ & $\mathrm{NT}$ & $\mathrm{NT}$ \\
$( \pm)-\mathbf{1 3 g}$ & 0.76 & 0.2 & 3.5 & 4.8 & 2.1 & 0.76 \\
$( \pm)-\mathbf{1 3 h}$ & 0.3 & $\mathrm{NT}$ & 2 & 1.6 & $>10$ & $>10$ \\
$( \pm)-\mathbf{1 3 i}$ & 1.2 & 1.8 & $\mathrm{NA}$ & 17.3 & $\mathrm{NA}$ & 27 \\
$( \pm)-\mathbf{1 5 a}$ & 0.8 & 1.5 & 4.9 & 8.3 & $\mathrm{NA}$ & 10 \\
$( \pm)-\mathbf{1 5 b}$ & 2.8 & $\mathrm{NT}$ & $>10$ & 3.6 & $>10$ & $>10$ \\
$( \pm)-\mathbf{1 5 c}$ & 0.15 & 0.2 & 0.4 & 0.8 & 0.7 & 2.3 \\
$( \pm)-\mathbf{1 5 d}$ & 0.09 & $\mathrm{NT}$ & 2.5 & 1.2 & $>10$ & $>10$ \\
$( \pm)-\mathbf{1 5 e}$ & 1 & 1.4 & 5 & 5 & $>10$ & $>10$ \\
$( \pm)-\mathbf{1 5 f}$ & 0.1 & 0.25 & 0.3 & $\mathrm{NT}$ & $>10$ & $>10$ \\
$( \pm)-\mathbf{1 5 g}$ & 1.5 & 2 & 5 & 5.5 & 18 & $>10$ \\
$( \pm)-\mathbf{1 5 h}$ & 0.4 & 2.5 & 2.3 & 1.5 & $>10$ & $>10$ \\
$( \pm)-\mathbf{1 5 i}$ & 0.4 & 0.3 & 2 & 2.5 & 40 & 39 \\
$( \pm)-\mathbf{1 5 j}$ & 1.6 & $\mathrm{NT}$ & 5 & $>10$ & $>10$ & $>10$ \\
$( \pm)-\mathbf{1 5 k}$ & $\mathrm{NA}$ & $\mathrm{NT}$ & $\mathrm{NT}$ & $\mathrm{NT}$ & $\mathrm{NT}$ & $\mathrm{NT}$ \\
$( \pm)-\mathbf{1 5 l}$ & 0.17 & $\mathrm{NT}$ & $>10$ & $>10$ & $>10$ & $>10$ \\
$( \pm)-\mathbf{2 1 a}$ & $>10$ & $\mathrm{NT}$ & $\mathrm{NT}$ & $\mathrm{NT}$ & $\mathrm{NT}$ & $\mathrm{NT}$ \\
$( \pm)-\mathbf{2 1 b}$ & 3.3 & 10 & 10 & 10 & $>10$ & $>10$ \\
efavirenz & 0.03 & 0.12 & 0.16 & 0.04 & 0.15 & 0.38 \\
nevirapine & 0.4 & 9 & 7 & 10 & 36 & 18 \\
\hline
\end{tabular}

${ }^{a}$ Inhibition of HIV-1 RT activities. All the data listed were compared to the corresponding test results for nevirapine, performed at the same time. Each value is the mean of at least three experiments; NA, not active, inhibition $\leq 10 \%$ at $100 \mu \mathrm{M}$ final drug; NT, not tested. ${ }^{b}$ From ref 8 a.

difference that arises at the NNBS level after K103N mutation (PDB code:1HQE) is that W229 bends down to Y181 and Y188 and the side chain of the latter establishes a H-bond interaction with N103 which consequently closes the NNRTI binding site. Accordingly, we hypothesize that the capability of NNRTIs to override $\mathrm{K} 103 \mathrm{~N}$ resistance could be related to their ability to penetrate the binding site by establishing a strong interaction with W229. Hence, the 3-methoxysubstituted phenyl ring of 13c $\left(K_{\mathrm{iK} 103 \mathrm{~N}}=0.022 \mu \mathrm{M}\right)$ penetrates in the aromatic cleft formed by W229, Y181, and Y188 more deeply in comparison to the benzo-fused moiety of 13d $\left(K_{\mathrm{iK} 103 \mathrm{~N}}=\mathrm{NA}\right)$, thereby establishing larger contacts with W229 (Figure 1A vs B).

With the aim of broadening the spectrum of activity against resistant RTs, we developed a new series of compounds characterized by an extended aromatic system at C-6, to enhance PBO interaction with the primer grip region (F227-H235), and in particular with the conserved amino acid W229, which faces on one side the NNBS and on the other side the catalytic site. Several analogues (15a-1, Table 2) were synthesized and tested, and the SARs of this novel set of NNRTI inhibitors is discussed herein.

Interaction studies clearly indicate that a phenyloxymethyl substituent in the para position (15c) of the PBO pendant phenyl ring at C- 6 is able to establish favorable interactions within wild-type HIV-1-RT NNBS This is demonstrated by the fact that 15c is eight times more active than compound $13 \mathbf{i}\left(\mathbf{1 5 c}, K_{\mathrm{i}}=0.15 \mu \mathrm{M} ; \mathbf{1 3 i}\right.$ $K_{\mathrm{i}}=1.20 \mu \mathrm{M}$, Table 2) and almost seven times more active than a PBO analogue bearing a methyl group at the same position $\left(K_{\mathrm{i}}=0.97 \mu \mathrm{M}^{8 \mathrm{a}}\right)$. It is noteworthy that the same effect is not observed when the phenyloxymethyl substituent is placed in the meta position, as demonstrated by the biological profile of compound $\mathbf{1 5 a}$ (RTwt $K_{\mathrm{i}}=0.80 \mu \mathrm{M}$ ). Among the new set of compounds, 15c can be considered as the most valuable compound, as it is active in the high nanomolar range against $R T w t$ and shows comparable activity toward all the common mutants tested, including K103N (Table 2). The presence of a second aromatic ring is crucial for activity, as demonstrated by the negligible efficacy shown by $\mathbf{1 5 b}$ and 15j. An extra phenyl ring was more suitable than a pyridine ring (15c vs 15i). The chemical nature of the linker between the two phenyl rings at C-6 can also affect the inhibitory activity. In particular, since a certain degree of flexibility is essential, a trans-ethylene tether led to an inactive analogue (15k). Moreover, the antienzymatic results obtained with $\mathbf{1 5 c}, \mathbf{1 5 d}$, and $\mathbf{1 5 l}$, characterized by a $\mathrm{CH}_{2} \mathrm{O}, \mathrm{CH}_{2} \mathrm{~N}, \mathrm{CH}_{2} \mathrm{CH}_{2}$ linker, respectively, evidenced that the different linkers did not affect RTwt inhibitory activity, while $\mathrm{CH}_{2} \mathrm{~N}(\mathbf{1 5 d})$ and $\mathrm{CH}_{2} \mathrm{CH}_{2}$ (15l) significantly decreased and/or abolished antienzymatic activity against mutated RTs. Similarly, the presence of an electron-withdrawing substituent, such as chlorine (15f), at C-3 of the second phenyl ring is well tolerated by the RTwt, but sensibly lowered the inhibitory activity against most of the mutants tested (15f vs 15c). Compound $\mathbf{1 5 h}$ in which the $\mathrm{CH}_{2} \mathrm{~N}$ linker was combined with a C-3' fluorine atom, showed a similar inhibitory profile as $\mathbf{1 5 d}$. On the contrary, $\mathbf{1 5 e}$ and $\mathbf{1 5 g}$, characterized by a substituent (chlorine and acetyl, respectively) at $\mathrm{C}-2$, showed negligible inhibitory activity toward RTwt and mutants.

On the basis of our design approach, the expected broad spectrum of activity of $\mathbf{1 5 c}$ could be due to its ability to establish extra-interactions with the aromatic residues present in the primer grip region. To prove this hypothesis the $(S)$-enantiomer of 15c was subjected to the same computational study applied to $\mathbf{1 3 c}$ and $\mathbf{1 3 d}$. As starting structures for flexible docking calculations several ligand conformers and different orientations with respect to RT NNBS were considered (see Experimental Section).

The docking results have been ranked by energy, and those energetically favored converged to the complex reported in Figure 2A. The proposed binding mode suggests that the tricyclic moiety is positioned similarly to 13c (see Figure 1A), with the benzo-fused ring giving favorable van der Waals contacts with L100 and V179, while the pyrrole moiety establishes a polarized edgeto-face $\pi-\pi$ interaction with Y318. On the other hand, the ethyl substituent at C-6 favorably interacts with V106 and F227, while the pendant 4-(phenyloxymethyl)phenyl moiety elongates in the aromatic pocket bound by Y188, Y181, and W229. Furthermore, contacts are also established with Y183, I94, P95, and Q91. In particular, some key interactions can be detected in this pocket: (i) a parallel displaced aromatic $\pi-\pi$ interaction with W229 (interaction energy $=-7.0 \mathrm{kcal} / \mathrm{mol}$ ), (ii) an alkyl-aryl interaction with the side chain of M230 (interaction energy $=-1.0 \mathrm{kcal} / \mathrm{mol}$ ), (iii) a polarized edge-to-face $\pi-\pi$ interaction with Y181 (interaction energy $=-5.2 \mathrm{kcal} / \mathrm{mol}$ ), with Y188 (interaction energy $=-4.9 \mathrm{kcal} / \mathrm{mol}$ ), and with Y183 (interaction energy $=$ $-2.5 \mathrm{kcal} / \mathrm{mol})$. The latter is part of the conserved YMDD motif ( $\beta 9-\beta 10$ hairpin) at the polymerase active site and its replacement, even with the conservative 


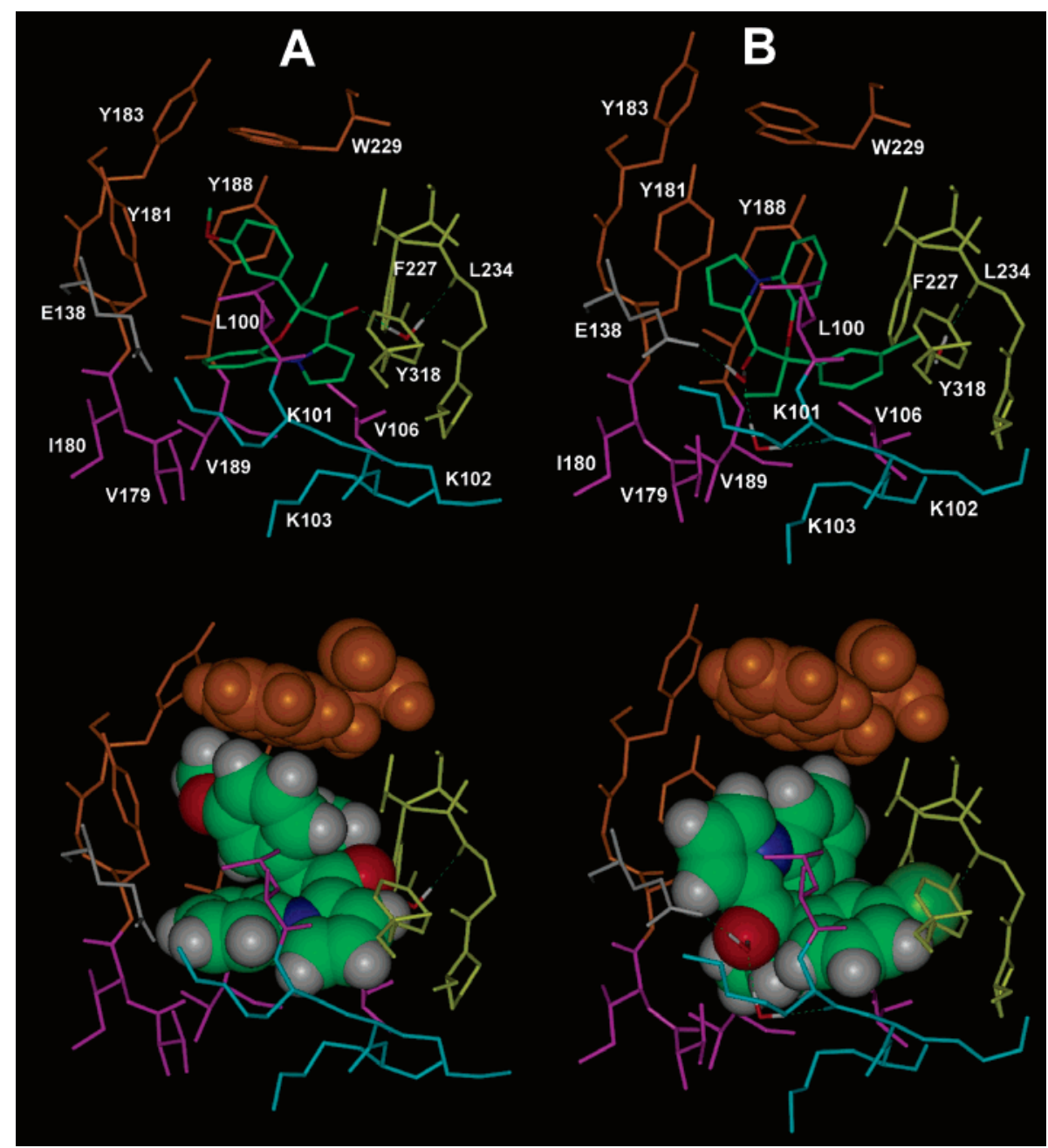

Figure 1. Compounds $(S)-13 c(A)$ and $(S)-13 d(B)$ docked into the HIV-1 RT NNBS. Residues lining the two aromatic clefts: (i) Y181, Y183, Y188 ( $\beta 9-\beta 10$ hairpin) and W229 ( $\beta 12-\beta 13$ hairpin, primer grip) and (ii) F227 (primer grip) and Y318 ( $\beta 15)$ are colored in orange and yellow, respectively; residues in the alkyl cleft are in magenta; lysines 101-103 are in cyan; E138 (p51 subunit) is in white. Ligands are colored by atom type. Bottom: Ligands and W229 are displayed with their van der Waals volumes. Hydrogen bonds are highlighted by green dashed lines. Amino acid hydrogens and water molecules are omitted for sake of clarity, with the exception of those involved in hydrogen bond interactions.

residue phenylalanine, causes an $80 \%$ reduction in HIV-1 RT polymerase activity. ${ }^{10}$ Hence, according to our docking results, the second phenyl ring of $\mathbf{1 5 c}$ protrudes toward the catalytic site of the enzyme through an extensive interaction with crucial residues in the primer grip region (F227, W229, M230) and in the $\beta 9-\beta 10$ hairpin (Y181, Y188, Y183) (Figure 2B).

With the aim to extend PBO SARs by varying the nature of the tricyclic skeleton, compounds $\mathbf{2 1 a}$ and $\mathbf{2 1 b}$, in which the oxygen-bridging atom (oxazepine) is replaced by a methylene moiety (azepine) have been synthesized. 21a and 21b showed a complete loss of activity toward RTwt and its mutants (Table 2). The conformational space of (S)-21b was sampled by 50 cycles of simulated annealing followed by energy minimization (see Experimental Section) in order to verify the energetic accessibility of the proposed PBO bioactive conformation. Indeed, the docking results highlighted that, despite their different binding mode to NNBS, all PBO compounds assume the same conformation at the C-6 phenyl ring $\left(\tau_{\mathrm{C}-7 / \mathrm{C}-6 / \mathrm{C}-1^{\prime} / \mathrm{C}-2^{\prime}}=20^{\circ}\right)$, even though their conformational space was extensively sampled through a Monte Carlo based approach during the docking procedure (all rotatable bond; $90 \%$ reduction of van der Waals and Coulombic terms, see Experimental Section). These results indicate the crucial role of this conformational requirement for PBO binding to HIV-1 RT NNBS. While the "bioactive conformation" of the pendant phenyl ring at C-6 is energetically accessible ( $\Delta \mathrm{E}$ from the global minimum $<5 \mathrm{kcal} / \mathrm{mol}$ ) for $13 \mathbf{c}, \mathbf{1 3 d}$, and $15 \mathbf{c}$, the bridged methylene in the seven membered ring of 21b prevents the proper orientation of the C-6 phenyl ring with respect to the tricyclic system $(\Delta E$ from the global minimum $>30 \mathrm{kcal} / \mathrm{mol}$ ). This is due to repulsive van der Waals interactions between the hydrogens of the bridged methylene and either the hydrogen at C-5', or the hydrogens of the ethyl substituent at C-6 (Figure S2, Supplementary Information).

Secondary Tests. A selected set of compounds active in enzymatic assays was evaluated for its ability to inhibit syncytia formation on C8166 cells infected with wild-type HIV-1IIIB virus. Furthermore, compounds 15c and 15f, representative of the new $\mathrm{PBO}$ series of antienzymatic agents, were further tested on monocyte macrophages infected with HTLV-III Ba-L (a laboratory adapted monocytotropic strain) in order to confirm their potential as antiviral agents. MTT assays were also conducted as a measure of the cytotoxic effect of the new 


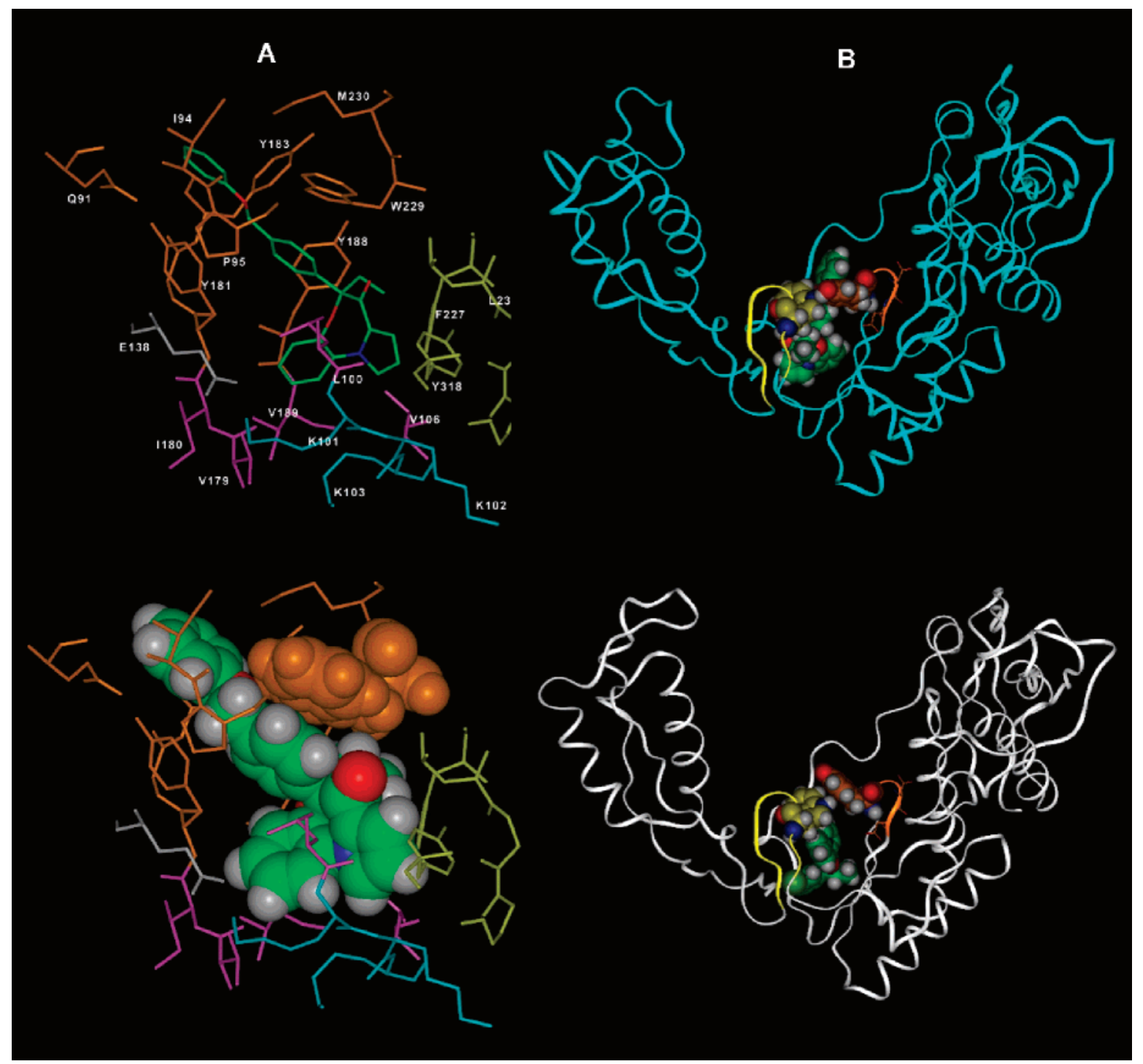

Figure 2. A: Compound $(S)$-15c (colored by atom type) docked into the HIV-1 RT NNBS. Residues lining the two aromatic clefts: (i) Y181, Y183, Y188 ( $\beta 9-\beta 10$ hairpin) and W229 ( $\beta 12-\beta 13$ hairpin, primer grip) and (ii) F227 (primer grip) and Y318 ( $\beta 15$ ) are colored in orange and yellow, respectively; residues in the alkyl cleft are in magenta; lysines 101-103 are in cyan; E138 (p51 subunit) is in white. Bottom: $(S)$-15c and W229 are displayed with their van der Waals volumes. B: Resulting docked complexes of $(S)$-15c/HIV-1 RT (top) and (S)-13d/HIV-1 RT (bottom). RT thumb, palm and finger domains are displayed as ribbons. The $\beta 12-\beta 13$ hairpin (primer grip) and $\beta 9-\beta 10$ hairpin (catalytic site) are shown in yellow and orange, respectively. van der Waals volumes of the ligands, W229, and Y188 are reported. D185 and D186 are displayed in stick. Amino acid hydrogens are omitted for sake of clarity, with the exception of those displayed with their van der Waals volumes.

compounds on four different cell lines and synergistic antiviral activity with AZT was calculated for the same antiviral agents.

Cell Culture and MTT Assays. The results are presented in Table 3. For the first generation PBOs 13d and 13e a weak antiviral activity was detected. In fact, on C8166 cells, both compounds showed $\mathrm{EC}_{50} \mathrm{~s}$ in the micromolar range. By comparing the data for 13d and 13e reported in Table 3 (C8166) with their antienzymatic activity an apparent discrepancy arose. In fact, 13d proved to be a potent inhibitor of RT wt while its $\mathrm{EC}_{50}$ on C8166 cells is $>2 \mu \mathrm{M}$. For the second generation PBO compounds bearing an extra aromatic ring $(\mathbf{1 5 c}, \mathbf{d}, \mathbf{f}, \mathbf{i})$, potent antiviral activity in C8166 infected cells comparable or superior to other previously described first generation PBOs was found. ${ }^{8 a}$ In particular, 15c showed a very potent antiviral efficacy in C8166 cells, similar to that of 8-ClTIBO, while its nitrogen-bridged counterpart 15d showed an $\mathrm{EC}_{50} 9$ times lower. Introduction of a chlorine atom in the meta position (i.e. 15f) of the phenyl ring of 15c slightly decreased the antiviral efficacy $\left(\mathrm{EC}_{50}=0.28 \mu \mathrm{M}\right)$. Even the replacement of the phenoxy group of $\mathbf{1 5 c}$ by a 3 -pyrydiloxy moiety (15i) led to an analogue characterized by a slightly decreased efficacy $\left(\mathbf{1 5 c} \mathrm{EC}_{50}=0.083\right.$ $\mu \mathrm{M}$ vs 15i $\left.\mathrm{EC}_{50}=0.18 \mu \mathrm{M}\right)$.

Furthermore, two representative derivatives (15c and 15f) were also studied on monocyte-macrophages infected by HTLV-III Ba-L (Table 4). HIV-1 infection of monocyte macrophages is an important event in the pathogenesis of AIDS. Monocyte-macrophages differ from $T$ cells in a number of aspects which could possibly affect the anti-HIV activity of some antiviral agents. In our case, 15c proved to be extremely potent in this test showing an $\mathrm{EC}_{50}$ of $2.0 \mathrm{nM}$. 15f was found to be 4 times less active than 15c, thus confirming the importance of the nanomolar efficacy of 15c. Their SIs are highly promising. When considered as a whole, the results 
Table 3. Inhibition of HIV-IIIB Replication in C8166 Cells, and Cytotoxicity on NSO Murine Cell Line, Daudi Human (DH) Cell Line, 3T3 Fibroblasts (3T3) Murine Cell Line, and Normal Human Lymphocytes (HL)

\begin{tabular}{|c|c|c|c|c|c|c|c|}
\hline \multirow[b]{2}{*}{ compd } & \multicolumn{3}{|c|}{$\mathrm{C} 8166$ cells $^{a}$} & \multicolumn{4}{|c|}{$\mathrm{TC}_{50}(\mathrm{mM})$} \\
\hline & $\begin{array}{l}\mathrm{CC}_{50} \\
(\mu \mathrm{M})^{b}\end{array}$ & $\begin{array}{l}\mathrm{EC}_{50} \\
(\mu \mathrm{M})^{c}\end{array}$ & $\mathrm{SI}^{d}$ & $\mathrm{NSO}^{e}$ & $\mathrm{DH}^{e}$ & $3 \mathrm{~T} 3 \mathrm{~F}^{e}$ & $\mathrm{HL}^{e}$ \\
\hline$( \pm)-\mathbf{1 3 d}$ & 7.5 & $>2$ & $<3.7$ & 0.081 & 0.084 & 0.081 & 0.08 \\
\hline$(=$ & 14.1 & 1.3 & 10.8 & 0.079 & 0.080 & 0.078 & 0.077 \\
\hline 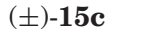 & 9.7 & 0.083 & 117 & 0.81 & 0.85 & 0.82 & 0.81 \\
\hline $15 d$ & 15.1 & 0.75 & 20.1 & 0.62 & 0.65 & 0.63 & 0.66 \\
\hline 101 & 10.7 & 0.4 & 22.3 & 0.72 & 0.74 & 0.70 & 0.72 \\
\hline$( \pm)-\mathbf{1 5 i}$ & 18.2 & 0.18 & 101 & 0.51 & 0.52 & 0.50 & 0.54 \\
\hline 8-ClTIBO & 50 & 0.030 & 1670 & & & & \\
\hline $\mathrm{AZT}$ & $>1$ & 0.0019 & $>526$ & & & & \\
\hline
\end{tabular}

${ }^{a}$ All the data listed were compared to the corresponding test results for AZT, which served as the treated control, and 8-CITIBO performed at the same time. ${ }^{b} \mathrm{CC}_{50}$ value is the test drug concentration which results in a 50\% survival of uninfected untreated control C8166 cells (e.g. cytotoxicity of the test drug). ${ }^{c}$ The $\mathrm{EC}_{50}$ value is the test drug concentration which produces a $50 \%$ survival of HIV-1 infected cells relative to uninfected untreated controls (e.g. in vitro anti-HIV-1 activity). ${ }^{d}$ SI, selectivity Index $\left(\mathrm{CC}_{50} / \mathrm{EC}_{50}\right) .{ }^{e}$ Blank was subtracted from O. D. measured at $570 \mathrm{~nm}$. All data reported are measured OD $\times 1000$. Standard deviations are not reported but never exceeded $5 \%$ of the mean value. ODs measured in control row were as follows: NSO 0.125 $\pm 0.015 ; \mathrm{DH} 0.129 \pm 0.018 ;$ 3T3F $0.131 \pm 0.014 ;$ HL $0.114 \pm 0.01$.

Table 4. Inhibition of HIV-1/BAL Replication in Monocyte-Macrophages by Compounds $\mathbf{1 5 c}, \mathbf{f}^{a}$

\begin{tabular}{lccc}
\hline compd & $\mathrm{CC}_{50}(\mu \mathrm{M})^{b}$ & $\mathrm{EC}_{50}(\mu \mathrm{M})^{c}$ & $\mathrm{SI}^{d}$ \\
\hline$( \pm)-\mathbf{1 5 c}$ & 16.8 & 0.002 & 8400 \\
$( \pm)-\mathbf{1 5 f}$ & 21.5 & 0.0084 & 2500 \\
AZT & $>100$ & 0.053 & $>1886$ \\
\hline
\end{tabular}

${ }^{a}$ Antiviral activity by HIV-1-p24 antigen production in monocyte-macrophages was determined 14 days after infection. For comparison, HIV-1-p24 antigen production in control cells was $22.789 \mathrm{pg} / \mathrm{mL}$. ${ }^{a}$ All the data listed were compared to the corresponding test results for AZT which served as the treated control, performed at the same time. ${ }^{b}$ The $\mathrm{CC}_{50}$ value is the test compound concentration which results in a 50\% survival of uninfected untreated control macrophages cells (e.g. cytotoxicity of the test drug). ${ }^{c}$ The $\mathrm{EC}_{50}$ value is the test drug concentration which produces a 50\% reduction of HIV-1-p24 antigen production in infected cells relative to uninfected untreated controls (e.g., in vitro anti-HIV-1 activity). ${ }^{d} \mathrm{SI}=$ selectivity Index $\left(\mathrm{CC}_{50} / \mathrm{EC}_{50}\right)$.

obtained using different infected cells indicate that 15c can be classified among the most potent second-generation anti-HIV agents.

Low cytotoxicities were also confirmed by screening the compounds in an MTT assay (3-(4,5-dimethylthiazol2-yl)2,5-diphenyltetrazolium bromide) using NSO murine, Daudi human, 3T3 fibroblast murine cell lines, and normal human limphocytes (Table 3). Compounds $\mathbf{1 5 c , d , f , i}$ showed weak cytotoxicity.

Synergistic Antiviral Activity with AZT. Resistance is a major concern in the chemotherapy of AIDS, and the recent therapeutic strategies have converged to favor multidrug regimens which are safer and more effective against the HIV-1 infection, with simultaneous reduction of drug dosages, toxicity, and resistance. A further improvement in multidrug therapy would be to administer combinations of drugs able to interact synergistically. ${ }^{20}$

Accordingly, to evaluate the potential of the new series of inhibitors in a multidrug approach, we investigated the synergistic antiviral activity of 15c in combination with the nucleoside analogue AZT (Table
Table 5. $\mathrm{EC}_{50}$ and Combination Index for Compound ( \pm )-15c in Association with AZT, Calculated Using Both the Mutually Nonexclusive and the Mutually Exclusive Assumption ${ }^{a}$

\begin{tabular}{lcccccc}
\hline & \multicolumn{3}{c}{$\mathrm{EC}_{50}(\mu \mathrm{M})$} & & \multicolumn{2}{c}{$\mathrm{CI}^{b}$} \\
\cline { 2 - 4 } \cline { 6 - 7 } $\begin{array}{c}\text { of } \\
\text { compd } \\
\text { alone }\end{array}$ & $\begin{array}{c}\text { of } \\
\text { compd } \\
\text { with AZT }\end{array}$ & $\begin{array}{c}\text { of AZT } \\
\text { with } \\
\text { compd }\end{array}$ & $\begin{array}{c}\text { mutually } \\
\text { exclusive } \\
\text { assumption }\end{array}$ & $\begin{array}{c}\text { mutually } \\
\text { nonexclusive } \\
\text { assumption }\end{array}$ \\
\hline $\begin{array}{l}\text { none } \\
( \pm) \text {-15c }\end{array}$ & 0.083 & 0.032 & 0.012 & & 0.52 & 0.525 \\
\hline
\end{tabular}

${ }^{a}$ C8166 cells were infected with HIV-IIIB. ${ }^{b} \mathrm{CI}>1, \mathrm{CI}=1$, CI $<1$ indicate antagonistic, additive, and synergistic activities, respectively. The CI values were calculated at 50\% antiviral activity using both mutually exclusive and mutually nonexclusive form of the equation.

5). The compound tested was able to potentiate the antiviral activity of AZT, and AZT was similarly able to potentiate the activity of 15c. The extent of the synergistic activity was quantified by the calculation of the combination index (CI) (as described by Chou and Talalay). Compound 15c showed a synergistic antiHIV-1 activity $(\mathrm{CI}<1)$ when tested in combination with AZT, notwithstanding the mutually exclusive or nonexclusive assumption formulas that were used (Table 5). Data shown in Table 5 confirm the new reverse transcriptase inhibitor $\mathbf{1 5 c}$ to be potentially useful in combination therapies.

\section{Conclusions}

In summary, our design strategy led to identification of a number of highly potent antiviral agents based on a PBO skeleton and structurally related to $\mathbf{5}$. Within the first generation of PBOs, focusing directly on a small number of structural alterations, we have been able to identify analogue 13d, a potent NNRTI, although it is characterized by weak antiviral activity. With the goal of developing more potent and broadspectrum analogues, we investigated second generation PBO NNRTIs, specifically designed to target the highly conserved amino acid residues within the $\beta 12-\beta 13$ hairpin (primer grip region). According to our hypothesis, the PBO derivative 15c proved to be very potent against the most common mutant enzymes, including the highly resistant K103N, Y181I, and Y188L mutant strains. Docking studies highlighted that the second phenyl ring of 15c protrudes toward the catalytic site, directly interacting with Y183, part of the conserved YMDD motif (polymerase active site, $\beta 9-\beta 10$ hairpin) and with crucial residues in the primer grip region (F227, W229, M230). The second generation PBO 15c showed a greatly improved pharmacological profile, in terms of efficacy, broad spectrum and low cytotoxicity. The antiviral activity and the synergistic antiviral properties with AZT suggest its potential clinical utility, in combination with NRTIs, against strains of HIV-1 bearing those mutations that confer resistance to the known NNRTIs.

\section{Experimental Section}

Melting points were determined using a Büchi Melting Point B-540 apparatus and are uncorrected. IR spectra were taken with Perkin-Elmer 398 and FT 1600 spectrophotometers. ${ }^{1} \mathrm{H}$ NMR spectra were recorded on a Bruker $200 \mathrm{MHz}$ spectrometer with TMS as internal standard; the values of chemicals shifts $(\delta)$ are given in ppm and coupling constants $(J)$ in $\mathrm{Hz}$. All reactions were carried out in an argon atmosphere. Thin- 
layer chromatography was performed on silica gel plates (Riedel-de Haen, Art.37341). Merk silica gel (Kieselgel 60) was used for chromatography (70-230 mesh) and flash chromatography (230-400 mesh) columns. Organic extracts were dried over $\mathrm{MgSO}_{4}$, and the solvents were removed under reduced pressure. Elemental analyses were performed on a Perkin-Elmer 240C elemental analyzer, and the results are within $\pm 0.4 \%$ of the theoretical values, unless otherwise noted (Table 5). Yields refer to purified products and are not optimized. Physical and chemical data for compound 13-21 were reported in Table 1.

General Procedure for Preparation of Compounds $( \pm)-\mathbf{8 a}-\mathbf{d}$. This procedure is illustrated for the preparation of $( \pm)$ - $\alpha$-bromo-(3-iodophenyl)acetic acid ethyl ester $(( \pm)-8 \mathbf{a}) . \mathrm{A}$ mixture of $3.44 \mathrm{~g}$ of $\mathbf{7 a}(11.8 \mathrm{mmol}), 1.89 \mathrm{~g}(10.6 \mathrm{mmol})$ of $N$-bromosuccinimide and a catalytic amount of AIBN in $70 \mathrm{~mL}$ of carbon tetrachloride was refluxed for $5 \mathrm{~h}$. After cooling at 0 ${ }^{\circ} \mathrm{C}$, the solution was concentrated, and the residue was washed with brine and purified by means of flash chromatography eluting with toluene to give ( \pm )-8a as a colorless oil (50\%): IR $\left(\mathrm{CHCl}_{3}\right) 1737 \mathrm{~cm}^{-1} ;{ }_{1}^{1} \mathrm{H}$ NMR $\left(\mathrm{CDCl}_{3}\right) \delta 1.28(\mathrm{t}, 3 \mathrm{H}, J=6.9$ $\mathrm{Hz}), 4.25(\mathrm{~m}, 2 \mathrm{H}), 5.22(\mathrm{~s}, 1 \mathrm{H}), 7.09(\mathrm{t}, 1 \mathrm{H}, J=7.9 \mathrm{~Hz}), 7.52$ $(\mathrm{d}, 1 \mathrm{H}, J=8.2 \mathrm{~Hz}), 7.67(\mathrm{~d}, 1 \mathrm{H}, J=7.8 \mathrm{~Hz}), 7.88(\mathrm{~s}, 1 \mathrm{H})$. Anal. $\left(\mathrm{C}_{10} \mathrm{H}_{10} \mathrm{BrIO}_{2}\right) \mathrm{C}, \mathrm{H}$.

General Procedure for Preparation of Compounds $( \pm)-10 a-\mathbf{e}$. This procedure is illustrated for the preparation of ( \pm )- $\alpha$-(3-chlorophenyl)- $\alpha$-[[2-(1H-pyrrol-1-yl)phenyl $]$ oxy]acetic acid ethyl ester $(( \pm)-\mathbf{1 0 a}) .0 .532 \mathrm{~g}(13.3 \mathrm{mmol}, 60 \%$ dispersion in mineral oil) of sodium hydride was added to a solution of $1.91 \mathrm{~g}$ (12 mmol) of 1-(2-hydroxyphenyl)pyrrole $\mathbf{9}$ in $50 \mathrm{~mL}$ of anhydrous THF. The mixture was stirred at room temperature for $1 \mathrm{~h}$; then a solution $3.3 \mathrm{~g}(12 \mathrm{mmol})$ of $( \pm)$ $\alpha$-bromo-(3-chlorophenyl)acetic acid ethyl ester in $15 \mathrm{~mL}$ of anhydrous THF was added dropwise. After stirring at reflux for $15 \mathrm{~h}$, the solvent was removed in vacuo, and the residue was taken up in dichloromethane and washed with a saturated solution of $\mathrm{NH}_{4} \mathrm{Cl}$. The organic layer was dried and evaporated. The residue was purified by means of flash chromatography (eluent: $n$-hexane/ethyl ether 4:1) to give ( \pm )-10a as a colorless oil (69\%): IR $\left(\mathrm{CHCl}_{3}\right) 1734 \mathrm{~cm}^{-1} ;{ }^{1} \mathrm{H} \mathrm{NMR}\left(\mathrm{CDCl}_{3}\right) \delta 1.17$ (t, 3 $\mathrm{H}, J=7.1 \mathrm{~Hz}), 4.15(\mathrm{q}, 2 \mathrm{H}, J=7.1 \mathrm{~Hz}), 5.45(\mathrm{~s}, 1 \mathrm{H}), 6.34$ (m, $2 \mathrm{H}), 7.08-7.45$ (m, $10 \mathrm{H})$. Anal. $\left(\mathrm{C}_{20} \mathrm{H}_{18} \mathrm{ClNO}_{3}\right) \mathrm{C}, \mathrm{H}, \mathrm{N}$.

General Procedure for Preparation of Compounds $( \pm)-11 a-\mathbf{e}$. This procedure is illustrated for the preparation of ( \pm -)- $\alpha$-ethyl- $\alpha$-(3-chlorophenyl)- $\alpha$-[[2-( $1 H$-pyrrol-1-yl)phenyl]oxy]acetic acid ethyl ester $(( \pm)-\mathbf{1 1 a})$. A solution of $3.0 \mathrm{~g}$ (8.4 mmol) of ( \pm -10a in $20 \mathrm{~mL}$ of anhydrous THF was slowly added to lithium diisopropylamide ( $8.4 \mathrm{~mL}, 16.8 \mathrm{mmol}, 2 \mathrm{M}$ in THF) at $-78{ }^{\circ} \mathrm{C}$. The mixture was stirred at $-78{ }^{\circ} \mathrm{C}$ for $2 \mathrm{~h}$, then $2.62 \mathrm{~g}$ ( $16.8 \mathrm{mmol})$ of ethyl iodide was added. The mixture was allowed to warm to room temperature and stirred for $1 \mathrm{~h}$, then was refluxed for an additional $2 \mathrm{~h}$. The solvent was removed under reduced pressure, and the residue was taken up in dichloromethane and washed with brine. The organic layers were collected, dried, and evaporated. The residue was purified by means of flash chromatography eluting with $n$-hexane/ethyl ether (4:1) to give $( \pm)$-11a as an oil $(76 \%)$ : IR $\left(\mathrm{CHCl}_{3}\right) 1760$ $\mathrm{cm}^{-1} ;{ }^{1} \mathrm{H}$ NMR $\left(\mathrm{CDCl}_{3}\right) \delta 0.89(\mathrm{t}, 3 \mathrm{H}, J=7.1 \mathrm{~Hz}), 1.10(\mathrm{t}, 3 \mathrm{H}$, $J=6.9 \mathrm{~Hz}), 2.40(\mathrm{~m}, 2 \mathrm{H}), 4.15(\mathrm{q}, 2 \mathrm{H}, J=7.1 \mathrm{~Hz}), 6.40(\mathrm{~m}$, $2 \mathrm{H}), 7.19(\mathrm{~m}, 10 \mathrm{H})$. Anal. $\left(\mathrm{C}_{22} \mathrm{H}_{22} \mathrm{ClNO}_{3}\right) \mathrm{C}, \mathrm{H}, \mathrm{N}$.

General Procedure for Preparation of Compounds $( \pm)-12 a-\mathbf{e}$. This procedure is illustrated for the preparation of ( \pm )- $\alpha$-ethyl- $\alpha$-(3-chlorophenyl)- $\alpha$-[[2-( $1 H$-pyrrol-1-yl)phenyl]oxy]acetic acid $(( \pm)-12 a)$. To a solution of $2.16 \mathrm{~g}(5.6 \mathrm{mmol})$ of ester $( \pm)-11 a$ in ethanol/THF 1:1 was added $10 \mathrm{~mL}$ of a $15 \%$ $\mathrm{NaOH}$ solution. The mixture was refluxed for $5 \mathrm{~h}$; then the organic solvents were evaporated and the water phase was acidified with $4 \mathrm{~N} \mathrm{HCl}$ until $\mathrm{pH} 3-4$. The resulting suspension was extracted with ethyl acetate, and the organic phase was washed with brine, dried, and concentrated to give $( \pm)-\mathbf{1 2 a}$ as an amorphous solid (89\%): IR $\left(\mathrm{CHCl}_{3}\right) 1767 \mathrm{~cm}^{-1} ;{ }^{1} \mathrm{H}$ NMR $\left(\mathrm{CDCl}_{3}\right) \delta 1.10(\mathrm{t}, 3 \mathrm{H}, J=6.9 \mathrm{~Hz}), 2.40(\mathrm{~m}, 2 \mathrm{H}), 6.40(\mathrm{~m}, 2$ $\mathrm{H}), 7.19(\mathrm{~m}, 10 \mathrm{H})$. Anal. $\left(\mathrm{C}_{20} \mathrm{H}_{18} \mathrm{ClNO}_{3}\right) \mathrm{C}, \mathrm{H}, \mathrm{N}$.
General Procedure for Preparation of Compounds $( \pm) \mathbf{- 1 3 d}-\mathbf{g}, \mathbf{i}$. This procedure is illustrated for the preparation of ( \pm -6-ethyl-6-(3-chlorophenyl)pyrrolo[2,1- $d][1,5]$-benzoxazepin7-(6H)-one $(( \pm)$-13d). Phosphorus pentachloride $(2.46 \mathrm{~g}, 11.8$ mmol) was added, in small portions, to a solution of $3.81 \mathrm{~g}$ $(10.7 \mathrm{mmol})$ of $( \pm)-\mathbf{1 2 a}$ in $40 \mathrm{~mL}$ of dry dichloromethane. The reaction mixture was stirred at room temperature for $12 \mathrm{~h}$, then was poured into crushed ice, basified with $10 \% \mathrm{NaOH}$ solution, and extracted with chloroform. The organic layers were washed with brine, dried, and evaporated. The residue was purified by means of flash chromatography (toluene/ dichloromethane 2:1) and recrystallized to yield $( \pm)-\mathbf{1 3 d}$ as yellow prisms: IR $\left(\mathrm{CHCl}_{3}\right) 1645 \mathrm{~cm}^{-1} ;{ }^{1} \mathrm{H} \mathrm{NMR}\left(\mathrm{CDCl}_{3}\right) \delta 0.95$ (t, $3 \mathrm{H}, J=7.0), 2.20-2.49(\mathrm{~m}, 2 \mathrm{H}), 6.47(\mathrm{~m}, 1 \mathrm{H}), 7.02-7.29$ $(\mathrm{m}, 9 \mathrm{H}), 7.48(\mathrm{~m}, 1 \mathrm{H})$. Anal. $\left(\mathrm{C}_{20} \mathrm{H}_{16} \mathrm{ClNO}_{2}\right) \mathrm{C}, \mathrm{H}, \mathrm{N}$.

( \pm )-6-Ethyl-6-(3-aminophenyl)-pyrrolo[2,1-d][1,5]benzoxazepin-7-(6H)-one $(( \pm)-13 \mathrm{~h}) .1 .15 \mathrm{~g}(10,6 \mathrm{mmol})$ of 1,3-propanedithol and $1.07 \mathrm{~g}(10.6 \mathrm{mmol})$ of anhydrous triethylamine were added to a solution of $1.22 \mathrm{~g}(3.54 \mathrm{mmol})$ of $( \pm)-\mathbf{1 3 g}$ in $15 \mathrm{~mL}$ of anhydrous THF. The mixture was stirred at room temperature for $48 \mathrm{~h}$. The solvent was removed under reduced pressure, and the residue was purified by means of flash chromatography using dichloromethane/methanol (2:1) as eluent to give $( \pm)-\mathbf{1 3 h}$ as prisms: IR (Nujol) $3380 \mathrm{~cm}^{-1}$, $1670 \mathrm{~cm}^{-1} ;{ }^{1} \mathrm{H}$ NMR $\left(\mathrm{CDCl}_{3}\right) \delta 1.03(\mathrm{t}, 3 \mathrm{H}, J=7.3 \mathrm{~Hz}), 2.02-$ $2.49(\mathrm{~m}, 2 \mathrm{H}), 3.54(\mathrm{br} \mathrm{s}, 2 \mathrm{H}), 6.45(\mathrm{~m}, 2 \mathrm{H}), 6.77(\mathrm{~m}, 1 \mathrm{H})$, $6.98(\mathrm{~m}, 1 \mathrm{H}), 7.01-7.23(\mathrm{~m}, 7 \mathrm{H})$. Anal. $\left(\mathrm{C}_{20} \mathrm{H}_{18} \mathrm{~N}_{2} \mathrm{O}_{2}\right) \mathrm{C}, \mathrm{H}$, N.

General Procedure for Preparation of Compounds $( \pm)-14 a, b$. This procedure is illustrated for the preparation of ( \pm )-6-ethyl-6-[4-(bromomethyl)phenyl]pyrrolo[2,1- $d][1,5]$ benzoxazepin-7(6H)-one $(( \pm)-14 a)$. A mixture of $1.5 \mathrm{~g}(4.73$ mmol) of ( \pm )-6-ethyl-6-( $p$-tolyl)pyrrolo[2,1- $d][1,5]$ benzoxazepin$7(6 H)$-one (( \pm -13a), $0.75 \mathrm{~g}(4.26 \mathrm{mmol})$ of $N$-bromosuccinimide, and a catalytic amount of $\alpha, \alpha^{\prime}$-azoisobutyronitrile in $60 \mathrm{~mL}$ of carbon tetrachloride was refluxed for $4 \mathrm{~h}$. The mixture was concentrated, and the residue was taken up in dichloromethane. The organic phase was washed with brine, dried, and concentrated in vacuo, and the residue was purified by means of flash chromatography ( $n$-hexane/ethyl acetate, $6: 1$ ) and recrystallized to give $( \pm)-\mathbf{1 4 a}$ as colorless prisms: IR (Nujol) $1703 \mathrm{~cm}^{-1} ;{ }^{1} \mathrm{H}$ NMR $\left(\mathrm{CDCl}_{3}\right) \delta 1.02(\mathrm{t}, 3 \mathrm{H}, J=7.2$ $\mathrm{Hz}), 2.22-2.36(\mathrm{~m}, 1 \mathrm{H}), 2.38-2.52(\mathrm{~m}, 1 \mathrm{H}), 4.40(\mathrm{~s}, 2 \mathrm{H})$, $6.45(\mathrm{t}, 1 \mathrm{H}, J=3.2 \mathrm{~Hz}), 7.08-7.46(\mathrm{~m}, 10 \mathrm{H})$. Anal. $\left(\mathrm{C}_{21} \mathrm{H}_{18} \mathrm{BrNO}_{2}\right) \mathrm{C}, \mathrm{H}, \mathrm{N}$.

General Procedure for Preparation of Compounds $( \pm)-15 \mathbf{a}-\mathbf{c}, \mathbf{e}-\mathbf{g}, \mathbf{i}$. This procedure is illustrated for the preparation of ( \pm )-6-ethyl-6-[3-(phenyloxymethyl)phenyl]pyrrolo[2,1d] [1,5]benzoxazepine-7 $(6 H)$-one $(( \pm)$-15a). To a solution of 26 $\mathrm{mg}(0.28 \mathrm{mmol})$ of phenol in $2 \mathrm{~mL}$ of anhydrous THF was added $30 \mathrm{mg}(0.31 \mathrm{mmol})$ of sodium tert-butoxide, and the resulting mixture was heated at $40{ }^{\circ} \mathrm{C}$. After $1 \mathrm{~h}$, a solution of $111.0 \mathrm{mg}(0.28 \mathrm{mmol})$ of $( \pm)-\mathbf{1 4 b}$ in $2.0 \mathrm{~mL}$ of anhydrous THF was slowly added, and the resulting mixture was stirred overnight. The solvent was removed in vacuo, and the residue was taken up in dichloromethane; the organic phase was washed with brine, dried, and concentrated. The residue was purified by means of flash chromatography eluting with dichloromethane to give ( \pm )-15a as a colorless oil: IR (Nujol) $1675 \mathrm{~cm}^{-1} ;{ }^{1} \mathrm{H} \mathrm{NMR}\left(\mathrm{CDCl}_{3}\right) \delta 1.05(\mathrm{t}, 3 \mathrm{H}, J=7.0 \mathrm{~Hz}), 2.40$ $(\mathrm{q}, 2 \mathrm{H}, J=7.0 \mathrm{~Hz}), 4.98(\mathrm{~s}, 2 \mathrm{H}), 6.45(\mathrm{~m}, 1 \mathrm{H}), 6.88-7.48(\mathrm{~m}$, $15 \mathrm{H})$. Anal. $\left(\mathrm{C}_{27} \mathrm{H}_{23} \mathrm{NO}_{3}\right) \mathrm{C}, \mathrm{H}, \mathrm{N}$.

General Procedure for Preparation of Compounds $( \pm)-15 d, h$. This procedure is illustrated for the preparation of ( \pm )-6-ethyl-6-[4-(phenylaminomethyl)phenyl]pyrrolo[2,1- $d]$ $[1,5]$ benzoxazepine- $7(6 H)$-one $(( \pm)-\mathbf{1 5 d})$. To a solution of $46 \mathrm{mg}$ of aniline $(0.5 \mathrm{mmol})$ in $3 \mathrm{~mL}$ of 2-butanone was added $83 \mathrm{mg}$ $(2.4 \mathrm{mmol})$ of potassium carbonate, and the mixture was stirred at reflux. After $2 \mathrm{~h}, 0.2 \mathrm{~g}(0.5 \mathrm{mmol})$ of $( \pm)-\mathbf{1 4 a}$ was added, and the resulting mixture was stirred overnight. The solvent was removed in vacuo; the residue was taken up in ethyl acetate and washed with brine. The organic phase was dried and concentrated, and the residue was purified by means of flash chromatography eluting with chloroform $/ n$-hexane 
(8:2). After recrystallization from $n$-hexane $( \pm)$-15e was obtained as white prisms: IR (Nujol) $1686 \mathrm{~cm}^{-1} ;{ }^{1} \mathrm{H} \mathrm{NMR}\left(\mathrm{CDCl}_{3}\right)$ $\delta 1.04(\mathrm{t}, 3 \mathrm{H}, J=7.6 \mathrm{~Hz}), 2.26-2.54(\mathrm{~m}, 2 \mathrm{H}), 4.24(\mathrm{~s}, 2 \mathrm{H})$, $6.45(\mathrm{~m}, 1 \mathrm{H}), 6.56(\mathrm{~d}, 2 \mathrm{H}, J=8.3 \mathrm{~Hz}), 6.94(\mathrm{t}, 1 \mathrm{H}, J=7.5$ $\mathrm{Hz}), 7.01-7.37(\mathrm{~m}, 12 \mathrm{H})$. Anal. $\left(\mathrm{C}_{27} \mathrm{H}_{24} \mathrm{~N}_{2} \mathrm{O}_{2}\right) \mathrm{C}, \mathrm{H}, \mathrm{N}$.

( \pm )-6-Ethyl-6-[4-[(2-imino-2,3-dihydro-1,3-thiazol-3-yl)methyl]phenyl]pyrrolo[2,1- $d][1,5]$ ben-zoxazepine- $7(6 H)$ one $(( \pm)-15 \mathbf{j})$. To a solution of $150 \mathrm{mg}(0.38 \mathrm{mmol})$ of $( \pm)-\mathbf{1 4 a}$ in $5 \mathrm{~mL}$ of 1-propanol was added $45 \mathrm{mg}(0.45 \mathrm{mmol})$ of 2 -aminothiazole, and the resulting mixture was refluxed overnight. The solvent was removed, and the residue was taken up in ethyl acetate and washed with brine. The organic phase was dried, concentrated, and purified by means of flash chromatography (dichloromethane/ethyl alcohol 6:1) to give $( \pm)-\mathbf{1 5 j}$ as a pale pink amorphous solid: ${ }^{1} \mathrm{H} \mathrm{NMR}\left(\mathrm{CDCl}_{3}\right) \delta$ $1.00(\mathrm{t}, 3 \mathrm{H}, J=7.1 \mathrm{~Hz}), 2.21-2.50(\mathrm{~m}, 2 \mathrm{H}), 4.56(\mathrm{br} \mathrm{s}, 1 \mathrm{H})$, $5.27(\mathrm{~s}, 2 \mathrm{H}), 6.45(\mathrm{~m}, 3 \mathrm{H}), 6.95-7.46(\mathrm{~m}, 10 \mathrm{H})$. Anal. $\left(\mathrm{C}_{24} \mathrm{H}_{21} \mathrm{~N}_{3} \mathrm{O}_{2} \mathrm{~S}\right) \mathrm{C}, \mathrm{H}, \mathrm{N}$.

$( \pm)$-6-Ethyl-6-[4-[(E)-2-phenylethenyl]phenyl]pyrrolo[2,1-d][1,5]benzoxazepine-7(6H)-one $(( \pm)$-15k). To a solution of $140 \mathrm{mg}(0.35 \mathrm{mmol})$ of $( \pm)-\mathbf{1 4 a}$ was added $1.26 \mathrm{~mL}(7$ $\mathrm{mmol}$ ) of triethyl phosphite, and the mixture was refluxed for $2 \mathrm{~h}$. The excess triethyl phosphite was removed by distillation, and the residue was dissolved in $3 \mathrm{~mL}$ of anhydrous THF. To the resulting mixture, cooled at $0{ }^{\circ} \mathrm{C}$, was added a suspension of $14 \mathrm{mg}(0.35 \mathrm{mmol})$ of sodium hydride $(60 \%$ dispersion in mineral oil) in $2 \mathrm{~mL}$ of anhydrous THF, and after stirring at room temperature for $1 \mathrm{~h}$, a solution of $42 \mathrm{mg}(0.4 \mathrm{mmol})$ of benzaldehyde in THF ( $1 \mathrm{~mL}$ ) was added. The mixture was heated to $60{ }^{\circ} \mathrm{C}$ for $5 \mathrm{~h}$, then stirred at room-temperature overnight. The solvent was removed under reduced pressure, the residue was taken up in dichloromethane and washed with a saturated solution of $\mathrm{NH}_{4} \mathrm{Cl}$, and the organic phase was separated, dried, and concentrated in vacuo. After purification by means of flash chromatography ( $n$-hexane/ethyl acetate $9: 1)$ and recrystallization from ethyl acetate/ $n$-hexane (1:4), the title compound was obtained as colorless prisms: ${ }^{1} \mathrm{H}$ NMR $\left(\mathrm{CDCl}_{3}\right)$ $\delta 1.05(\mathrm{t}, 3 \mathrm{H}, J=7.5 \mathrm{~Hz}), 2.27-2.56(\mathrm{~m}, 2 \mathrm{H}), 6.46(\mathrm{~m}, 1 \mathrm{H})$, 7.03-7.49 (m, $17 \mathrm{H})$. Anal. $\left(\mathrm{C}_{28} \mathrm{H}_{23} \mathrm{NO}_{2}\right) \mathrm{C}, \mathrm{H}, \mathrm{N}$.

( \pm )-6-Ethyl-6-[4-(2-phenylethyl)phenyl]pyrrolo[2,1-d]$[1,5]$ benzoxazepine-7 $(6 H)$-one $(( \pm)-15 l)$. The title compound was obtained by catalytic hydrogenation $(90 \mathrm{mg}$ of $10 \%$ palladium on charcoal) of a solution of $54 \mathrm{mg}(0.13 \mathrm{mmol})$ of $( \pm)$-15k in $10 \mathrm{~mL}$ of methyl alcohol at atmospheric pressure and room temperature. After purification by means of flash chromatography ( $n$-hexanes - ethyl acetate 8:1) and recrystallization from ethyl acetate/ $n$-hexane (1:6), compound $( \pm)$-15o was obtained as white prisms: ${ }^{1} \mathrm{H}$ NMR $\left(\mathrm{CDCl}_{3}\right) \delta 1.06$ (t, 3 $\mathrm{H}, J=7.3 \mathrm{~Hz}), 2.25-2.55(\mathrm{~m}, 2 \mathrm{H}), 2.83(\mathrm{~s}, 4 \mathrm{H}), 6.46(\mathrm{~m}, 1$ $\mathrm{H}), 6.93-7.26(\mathrm{~m}, 15 \mathrm{H})$. Anal. $\left(\mathrm{C}_{28} \mathrm{H}_{25} \mathrm{NO}_{2}\right) \mathrm{C}, \mathrm{H}, \mathrm{N}$.

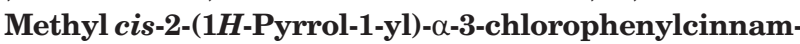
ate (17). To $3.0 \mathrm{~g}$ (11.4 mmol) of ( \pm )- $\alpha$-bromo-3-chlorophenyl acetic acid methyl ester ${ }^{15 \mathrm{a}}$ was added $5.68 \mathrm{~g}(34.2 \mathrm{mmol})$ of triethyl phosphite, and the resulting mixture was refluxed for $2 \mathrm{~h}$. The excess triethyl phoshite was distilled under vacuum, and the residue was dissolved in $20 \mathrm{~mL}$ of anhydrous THF. This solution was slowly added to a cooled $\left(0^{\circ} \mathrm{C}\right)$ suspension of $456 \mathrm{mg}$ of sodium hydride ( $11.4 \mathrm{mmol}, 60 \%$ dispersion in mineral oil) in $5 \mathrm{~mL}$ of anhydrous THF. Stirring was then maintained for $10 \mathrm{~min}$ at room temperature, then a solution of $1.37 \mathrm{~g}$ (11.4 mmol) of aldehyde $\mathbf{1 6}^{15}$ was added dropwise, and the resulting mixture was warmed at $50{ }^{\circ} \mathrm{C}$. After $1 \mathrm{~h}$, the solvent was removed under reduced pressure, and the residue was taken up in dichloromethane, washed with brine, dried, and evaporated under vacuum. The residue was purified by means of flash chromatography ( $n$-hexane/ethyl acetate 4.5 : $0.5)$ to give $\mathbf{1 7}$ as a pale yellow oil: ${ }^{1} \mathrm{H} \mathrm{NMR}\left(\mathrm{CDCl}_{3}\right) \delta 3.70(\mathrm{~s}$, $3 \mathrm{H}), 6.33(\mathrm{~m}, 2 \mathrm{H}), 6.79(\mathrm{~d}, 1 \mathrm{H}, J=3.7 \mathrm{~Hz}), 6.94(\mathrm{~m}, 2 \mathrm{H})$, 7.16-7.45 (m, $8 \mathrm{H})$. Anal. $\left(\mathrm{C}_{20} \mathrm{H}_{16} \mathrm{ClNO}_{2}\right) \mathrm{C}, \mathrm{H}, \mathrm{N}$.

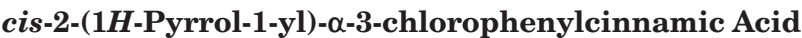
(18). To a solution of $1.4 \mathrm{~g}(4.14 \mathrm{mmol})$ of ester 17 in $25 \mathrm{~mL}$ of a mixture of methanol and THF (1:1) was added $8.5 \mathrm{~mL}(8.5$ $\mathrm{mmol}$ ) of a $10 \%$ aqueous solution of lithium hydroxide. The mixture was stirred at room temperature until consumption of the starting material as observed by TLC ( $n$-hexane/ethyl acetate 4.5:0.5), then was concentrated under reduced pressure to a small volume and acidified ( $\mathrm{pH} 3-4$ ) by addition of a $6 \mathrm{M}$ hydrochloric acid. The resulting suspension was extracted with ethyl acetate; the organic phase was dried and concentrated under reduced pressure to give $\mathbf{1 8}$ as a pale yellow oil: ${ }^{1} \mathrm{H}$ NMR $\left(\mathrm{CDCl}_{3}\right) \delta 6.37(\mathrm{~m}, 2 \mathrm{H}), 6.89(\mathrm{~m}, 1 \mathrm{H}), 6.99(\mathrm{~m}, 2 \mathrm{H}), 7.22-$ $7.51(\mathrm{~m}, 7 \mathrm{H}), 7.62(\mathrm{~d}, 1 \mathrm{H}, J=7.2 \mathrm{~Hz}), 10.46$ (br s, $1 \mathrm{H}$ ). Anal. $\left(\mathrm{C}_{19} \mathrm{H}_{14} \mathrm{ClNO}_{2}\right) \mathrm{C}, \mathrm{H}, \mathrm{N}$.

5-[(3-Chloro)]phenyl-4H-pyrrolo[1,2-a][1]benzoxazepin4-one (19). The title compound was obtained as previously described for 13d, starting from $1.2 \mathrm{~g}(3.7 \mathrm{mmol})$ of $\mathbf{1 8}$, and $854 \mathrm{mg}$ ( $4.1 \mathrm{mmol})$ of phosphorus pentachloride. After purification by means of flash chromatography (dichloromethane) the title compound was obtained as an amorphous solid: ${ }^{1} \mathrm{H}$ $\mathrm{NMR}\left(\mathrm{CDCl}_{3}\right) \delta 6.58(\mathrm{~m}, 1 \mathrm{H}), 7.20-7.62(\mathrm{~m}, 11 \mathrm{H})$. Anal. $\left(\mathrm{C}_{19} \mathrm{H}_{12} \mathrm{ClNO}\right) \mathrm{C}, \mathrm{H}, \mathrm{N}$.

( \pm )-5,6-Dihydro-5-(3-chlorophenyl)- $4 H$-pyrrolo[1,2-a][1]benzoxazepin-4-one $(( \pm)-20 \mathrm{~b})$. To a solution of $350 \mathrm{mg}$ $(1.14 \mathrm{mmol}$ ) of $19 \mathrm{in} 20 \mathrm{~mL}$ of THF was added $80 \mathrm{mg}$ of $10 \%$ palladium on charcoal. The mixture was stirred for $3 \mathrm{~h}$ at room temperature, then the catalyst was removed by filtration through Celite, and the clear solution concentrated under vacuum to give a residue which was chromatographed (petrolum ether 40-60/ethyl acetate 8:1) to give ( \pm -20b as a pale yellow oil: ${ }^{1} \mathrm{H}$ NMR $\left(\mathrm{CDCl}_{3}\right) \delta 3.29(\mathrm{~m}, 1 \mathrm{H}), 3.92(\mathrm{~m}, 1 \mathrm{H})$, $6.53(\mathrm{~m}, 1 \mathrm{H}), 7.05-7.38(\mathrm{~m}, 11 \mathrm{H})$. Anal. $\left(\mathrm{C}_{19} \mathrm{H}_{14} \mathrm{ClNO}\right) \mathrm{C}, \mathrm{H}$, $\mathrm{N}$.

( \pm )-5-Ethyl-5,6-dihydro-5-phenyl-4H-pyrrolo[1,2-a][1]benzoxazepin-4-one $(( \pm)-21 a)$. To a suspension of potassium hydride ( $83 \mathrm{mg}, 0.62 \mathrm{mmol}$ ) in $2 \mathrm{~mL}$ of anhydrous THF, cooled at $0{ }^{\circ} \mathrm{C}$, was slowly added a solution of $169 \mathrm{mg}(0.62 \mathrm{mmol})$ of ( \pm )-5,6-dihydro-5-phenyl-4H-pyrrolo[1,2-a][1]benzoxazepin-4one $^{15 \mathrm{~b}}$ in $3 \mathrm{~mL}$ of anhydrous THF. The mixture was stirred at room temperature for $1.5 \mathrm{~h}$, then $97 \mathrm{mg}(0.62 \mathrm{mmol})$ of iodoethane was added. After stirring for a further $24 \mathrm{~h}$, the solvent was removed under reduced pressure, and the residue was taken up in dichloromethane. The organic phase was washed with brine, dried, and concentrated in vacuo. The residue was crystallized to give $( \pm)-\mathbf{2 1 a}$ as colorless prisms: IR (Nujol) $1693 \mathrm{~cm}^{-1} ;{ }^{1} \mathrm{H} \mathrm{NMR}\left(\mathrm{CDCl}_{3}\right) \delta 1.10$ (t, $3 \mathrm{H}, J=7.2$ $\mathrm{Hz}), 2.08(\mathrm{~m}, 1 \mathrm{H}), 2.28(\mathrm{~m}, 1 \mathrm{H}), 3.09(\mathrm{~d}, 1 \mathrm{H}, J=13.8), 3.58$ $(\mathrm{d}, 1 \mathrm{H}, J=13.8 \mathrm{~Hz}), 6.42(\mathrm{~m}, 1 \mathrm{H}), 6.89(\mathrm{~m}, 1 \mathrm{H}), 6.98-7.25$ $(\mathrm{m}, 10 \mathrm{H})$. Anal. $\left(\mathrm{C}_{21} \mathrm{H}_{19} \mathrm{NO}\right) \mathrm{C}, \mathrm{H}, \mathrm{N}$

HIV-1 RT RNA-Dependent DNA Polymerase Activity Assay. Inhibition Assay. RNA-dependent DNA polymerase activity assay was assayed as follows: a final volume of 25 $u \mathrm{M}$ contained reaction buffer $(50 \mathrm{mM}$ Tris- $\mathrm{HCl} \mathrm{pH} \mathrm{7.5,1 \textrm {mM }}$ DTT, $0.2 \mathrm{mg} / \mathrm{mL}$ BSA, $4 \%$ glycerol), $10 \mathrm{mM} \mathrm{MgCl} 2,0.5 \mu \mathrm{g}$ of poly(rA)oligo(dT)10:1 (0.3 $\mu \mathrm{M}$ 3'-OH ends), $10 \mu \mathrm{M}$ [3H]-dTTP ( $1 \mathrm{Ci} / \mathrm{mmol}$ ), and 2-4 $\mathrm{nM}$ RT. Reactions were incubated at 37 ${ }^{\circ} \mathrm{C}$ for the indicated time. A total of $20 \mu \mathrm{L}$ aliquots were then spotted on glass fiber filters GF/C which were immediately immersed in 5\% ice-cold TCA. Filters were washed twice in $5 \%$ ice-cold TCA and once in ethanol for 5 min and dried, and acid-precipitable radioactivity was quantitated by scintillation counting. ${ }^{21}$

Reactions were performed under the conditions described for the HIV-1 RT RNA-dependent DNA polymerase activity assay. Incorporation of radioactive dTTP into poly(rA)/oligo(dT) was monitored in the presence of increasing amounts of the inhibitors to be tested. Data were then plotted according to Lineweaver-Burke and Dixon. For $K_{\mathrm{i}}$ determinations, an interval of inhibitor concentrations between $0.2 K_{\mathrm{i}}$ and $5 K_{\mathrm{i}}$ was used. Experiments have been done in triplicate. Experimental errors ( $\pm \mathrm{SD}$ ) were $e \leq 10 \%$.

In Vitro Anti-HIV Assays. Cell Culture Assay. 1. Mature macrophages were obtained by incubating in 48-well plates (Costar, Cambridge, MA) $106 \mathrm{PBMC} / \mathrm{mL}$ of complete medium (containing Roswell Park Memorial Institute (RPMI)-1640, penicillin 100 units $/ \mathrm{mL}$, streptomycin $100 \mathrm{mg} / \mathrm{mL}$, L-glutamine $0.3 \mathrm{mg} / \mathrm{mL}$, and $20 \%$ heat-inactivated fetal calf serum). After 7 days of incubation in $5 \% \mathrm{CO}_{2}$ at $37{ }^{\circ} \mathrm{C}$, nonadherent cells (lymphocytes) were removed by extensive washing. Using this 
method, the yield, after removal of the nonadherent cells, was 105 macrophages per well. Test was conducted as described elsewhere. ${ }^{22}$ Macrophages obtained with this method are $>95 \%$ pure as detected by nonspecific esterase activity. C8166 is a CD4+ T-cell line containing an HTLV-I genome of which only the tat gene is expressed. ${ }^{23}$

2. Virus. A laboratory lymphocyte-tropic strain of HIV-1 (HIV-1-IIIB) was used to infect C8166, while macrophages were infected with a laboratory monocyte-tropic strain of HIV-1 (HTLV-III-Ba-L, also called HIV-Ba-L). ${ }^{24,25}$ Titration to determine the infectivity was performed in human macrophages as previously described. The titer of the virus stocks, expressed as 50\% tissue culture infectious dose (TCID50), was determined as previously described. ${ }^{26}$

3. Antiviral Agent. Zidovudine (AZT) was purchased from Sigma Chimica. Efavirenz was a gift from Dr. Massimo Pregnolato, University of Pavia, Italy.

4. Toxicity. Chemicals toxicity in C8166 was evaluated with a procedure involving a colorimetric assay (MTT assay) that monitors the ability of viable, but not dead, cells to reduce 3-(4,5-dimethylthiazol-2-yl)-2,5-diphenyltetrazolium bromide (MTT) to a blue formazan product, which can be measured spectrophotometrically. ${ }^{27,28}$

5. Assay of Antiviral Activity. Antiviral activity of the tested compounds in acutely infected C8166 cultures was performed following an already described procedure. ${ }^{29}$ The assay to evaluate anti-HIV drug efficacy in acutely infected mature macrophages has been previously described. ${ }^{33}$ The antiviral activity of the compounds was assessed by measuring HIV-p24 antigen production in the supernatants of infected cultures as previously described ${ }^{24}$ by using a commercially available HIV-antigen kit.

6. Immunofluorescence Virus Binding Assay. Calculation of the $50 \%$ effective dose $\left(\mathrm{ED}_{50}\right)$ and $50 \%$ inhibitory dose $\left(\mathrm{ID}_{50}\right)$ was performed. The $\mathrm{ED}_{50}$ and $\mathrm{ID}_{50}$ values were calculated from pooled values in the effective dynamic range of the antiviral and toxicity assays (5-95\%) using the median effect equation as previously described..$^{30}$

Synergy Calculations. The multiple drug effect analysis of Chou and Talalay ${ }^{31}$ was used to calculate combined drug effects.

Acknowledgment. This work has been partially supported by the ISS Programma Nazionale di Ricerca sull' AIDS (Contract 30C.70) and by the CNR Target Project on Biotechnology to S.S.

Supporting Information Available: Experimental procedures for compounds $6 \mathbf{b}, \mathbf{c}, 7 \mathbf{a}-\mathbf{e}, 8 \mathbf{b}-\mathbf{d}, \mathbf{1 0 d}-\mathbf{e}, \mathbf{1 1 b}-\mathbf{e}$, 12b-e, 13e-g,i, 14b, 15b,c,e-i, 21b, molecular modeling and toxicity tests, Figures S1 and S2, and a table with elemental analyses of compounds described. This material is available free of charge via the Internet at http://pubs.acs.org.

\section{References}

(1) De Clercq, E. HIV Inhibitors Targeted at the Reverse Transcriptase. AIDS Res. Hum. Retroviruses 1992, 8, 119-134.

(2) Mitsuya, H.; Yarchoan, R.; Broder, S. Molecular targets for AIDS therapy. Science 1990, 249, 1533-1544.

(3) Kaufmann, G. R.; Cooper, D. A. Antiretroviral therapy of HIV-1 infection: Established treatment strategies and new therapeutic options. Curr. Opin. Microb. 2000, 3, 508-514.

(4) Vella, S.; Palmisano, L. Antiretroviral therapy: state of the HAART. Antiviral Res. 2000, 45, 1-7.

(5) Richman, D.; Shih, C.-K.; Lowy, I.; Rose, J.; Prodanovich, P.; Goff, S.; Griffin, J. Human immunodeficiency virus type 1 mutants resistant to nonnucleoside inhibitors of reverse transcriptase arise in tissue culture. Proc. Natl. Acad. Sci. U.S.A 1991, 88, 11241-11245.

(6) Schinazi, R. F.; Larder, B. A.; Mellors, J. W. Mutations in retroviral genes associated with drug resistance. Int. Antiviral News 1997, 5, 129-135.

(7) Young, S. D.; Britcher, S. F.; Tran, L. O.; Payne, L. S.; Lumma, W. C.; Lyle, T. A.; Huff, J. R.; Anderson, P. S.; Olsen, D. B.; Carroll, S. S.; Pettibone, D. J.; O’Brien, J. A.; Ball, R. G.; Balani, S. K.; Lin, J. H.; Chen, I.-W.; Schleif, W. A.; Sardana, V. V.; Long,
W. J.; Byrnes, V. W.; Emini, E. A. L-743,726 (DMP-266): a novel, highly potent nonnucleoside inhibitor of the human immunodeficiency virus type 1 reverse transcriptase. Antimicrob. Agents Chemother. 1995, 39, 2602-2605.

(8) (a) Campiani, G.; Morelli, E.; Fabbrini, M.; Nacci, V.; Greco, G.; Novellino, E.; Ramunno, A.; Maga, G.; Spadari, S.; Caliendo, G.; Bergamini, A.; Faggioli, E.; Uccella, I.; Bolacchi, F.; Marini, S.; Coletta, M.; Nacca, A.; Caccia, S. Pyrrolobenzoxazepinone Derivatives as Non-Nucleoside HIV-1 RT Inhibitors: Further Structure-Activity Relationship Studies and Identification of More Potent Broad-Spectrum HIV-1 RT Inhibitors with Antiviral Activity. J. Med. Chem. 1999, 42, 4462-4470, and references therein. (b) Watkinson, J. G.; Watson, W.; Yates, B. L. The effects of ortho substituents on reactivity. I. The alkaline hydrolysis of substituted ethyl phenylacetates. J. Chem. Soc. 1963, 54375444. (c) Pitrè, D.; Fumagalli, L., Lorenzotti, E. Radiological contrast media. XXI. Iodo derivatives of aryl[3-(N-alkylacylamino)phenoxy]acetic acids. Il Farmaco-Ed. Sc. 1972, 27, 408418. (d) Guanti, G.; Banfi, L.; Riva, R. Regioselective synthesis of 1,8-dihydroxytetralins through a tandem reduction/intramolecular hydroxyalkylation of 4-(3-hydroxyphenyl)alkanoates Tetrahedron 1994, 50, 11945-11966. (e) Epstein, J. W.; Brabander, H. J.; Fanshawe, W. J.; Hofmann, C. M.; McKenzie, T. C.; Safir, S. R.; Osterberg, A. C.; Cosulich, D. B.; Lovell, F. M. 1-Aryl-3-azabicyclo[3.1.0]hexanes, a new series of nonnarcotic analgesic agents. J. Med. Chem. 1981, 24, 481-490.

(9) (a) Maga, G.; Ramunno, A.; Nacci, V.; Locatelli, G. A.; Spadari, S.; Fiorini, I.; Baldanti, F.; Paolucci, S.; Zavattoni, M.; Bergamini, A.; Galletti, B.; Muck, S.; Hubsher, U.; Giorgi, G.; Guiso, G.; Caccia, S.; Campiani, G. The Stereoselective Targeting of a Specific Enzyme-Substrate Complex Is the Molecular Mechanism for the Synergic Inhibition of HIV-1 Reverse Transcriptase by (R)-(-)-PPO464. J. Biol. Chem. 2001, 48, 44653-44662. (b) Locatelli, G. A.; Campiani, G.; Cancio, R.; Morelli, E.; Ramunno, A.; Gemma, S.; Hubscher, U.; Spadari, S.; Maga, G. Effects of drug resistance mutations L100I and V106A on the binding of pyrrolobenzoxazepinone nonnucleoside inhibitors to the human immunodeficiency virus type 1 reverse transcriptase catalytic complex. Antimicrob Agents Chemother. 2004, 48, 15701580.

(10) Jacobo-Molina, A.; Ding, J.; Nanni, R. G.; Clark, A. D., Jr.; Lu, X.; Tantillo, C.; Williams, R. L.; Kamer, G.; Ferris, A. L.; Clark, P.; Hizi, A.; Hughes, S. H.; Arnold, E. Crystal structure of human immunodeficiency virus type 1 reverse transcriptase complexed with double-stranded DNA at 3.0 A resolution shows bent DNA. Proc Natl Acad Sci U.S.A. 1993, 90, 6320-6324.

(11) (a) Wohrl, B. M.; Krebs, R.; Thrall, S. H.; Le Grice, S. F.; Scheidig, A. J.; Goody, R. S. Kinetic analysis of four HIV-1 reverse transcriptase enzymes mutated in the primer grip region of $\mathrm{p}$ 66. Implications for DNA synthesis and dimerization. J. Biol. Chem. 1997, 272, 17581-44662. (b) Ghosh, M.; Williams, J.; Powell, M. D.; Levin, J. G.; Le Grice, S. F. Mutating a conserved motif of the HIV-1 reverse transcriptase palm subdomain alters primer utilization. Biochemistry 1997, 36, 5758-5768. (c) Pelemans, H.; Esnouf, R.; De Clerq, E.; Balzarini, J. Mutational Analysis of Trp-229 of Human Immunodeficiency Virus Type 1 Reverse Transcriptase (RT) Identifies This Amino Acid Residue as a Prime Target for the Rational Design of New NonNucleoside RT Inhibitors Mol. Pharmacol. 2000, 57, 954-960. (d) Pelemans, H.; Esnouf, R.; Min, K.; Parniak, M.; De Clerq E.; Balzarini, J. Mutation at Amino Acid Positions 63, 189, and 396 of Human Immunodeficiency Virus Type 1 Reverse Transcriptase (RT) Partially Restore the DNA Plymerase Activity of a TRP229TYR Mutant RT. Virology 2001, 287, 143-150.

(12) Ding, J.; Das, K.; Hsiou, Y.; Sarafianos, S. G.; Clark, A. D., Jr. Jacobo-Molina, A.; Tantillo, C.; Hughes, S. H.; Arnold, E. Structure and functional implications of the polymerase active site region in a complex of HIV-1 RT with a double-stranded DNA template-primer and an antibody Fab fragment at $2.8 \mathrm{~A}$ resolution. J. Mol. Biol. 1998, 284, 1095-111.

(13) Huang, H.; Chopra, R.; Verdine, G. L.; Harrison S. C. Structure of a Covalently Trapped Catalytic Complex of HIV-1 Reverse Transcriptase: Implications for Drug Resistance. Science 2004, 306, 1901-1902.

(14) Campiani, G.; Ramunno, A.; Fiorini, I.; Nacci, V.; Morelli, E.; Novellino, E.; Goegan, M.; Mennini, T.; Sullivan, S.; Zisterer, D. M.; Williams, C. D. Synthesis of New Molecular Probes for Investigation of Steroid Biosynthesis Induced by Selective Interaction with Peripheral Type Benzodiazepine Receptors (PBR). J. Med. Chem. 2002, 45, 4276-4281.

(15) (a) Dhanoa, D. S.; Bagley, S. W.; Chang, R. S. L.; Lotti, V. J.; Chen, T.-B.; Kivlighn, S. D.; Zingaro, G. J.; Siegl, P. K. S.; Chakravarty, P. K.; Patchett, A. A.; Greenlee, W. J. (Dipropylphenoxy) Phenylacetic Acids: a New Generation of Nonpeptide Angiotensin II Receptor Antagonists. J. Med. Chem. 1993, 36 , 
3738-3742. (b) Garofalo, A.; Ragno, G.; Campiani, G.; Brizzi, A.; Nacci, V. Polycondensed Heterocycles. Part 11: Preparation and Regioselective Reductions of 5-Phenyl-4H-pyrrolo[1,2-a][1]benzazepin-4-one. Tetrahedron 2000, 56, 9351-9355.

(16) Campiani, G.; Nacci, V.; Fiorini, I.; De Filippis, M. P.; Garofalo, A.; Greco, G.; Novellino, E.; Altamura, S.; Di Renzo, L. Pyrrolobenzothiazepinones and Pyrrolobenzoxazepinones: Novel and Specific Non-Nucleoside HIV-1 Reverse Transcriptase Inhibitors with Antiviral Activity. J. Med. Chem. 1996, 39, 2672-2680.

(17) PDB codes: 1BQM, 1BQN, 1COT, 1COU, 1C1B, 1C1C, 1DTQ, 1DTT, 1EET, 1EP4, 1FK9, 1FKO, 1FKP, 1HAR, 2HMI, 1HMV, 1HNI, 1HPZ, 1HQE, 1HQU, 1HRH, 1HVU, 1HYS, 1IKV, 1IKW $1 \mathrm{IKX}, 1 \mathrm{IKY}, 1 \mathrm{~J} 5 \mathrm{O}, 1 \mathrm{JKH}, \mathrm{IJLA}, 1 \mathrm{JLB}, 1 \mathrm{JLC}, 1 \mathrm{JLE}, 1 \mathrm{JLF}$ 1JLG, 1JLQ, 1KLM, 1N5Y, 1N6Q, 1RT3, 1RT4, 1RTD, 1RTI, 1VRT, 1VRU

(18) Das, K.; Clark, A. D., Jr.; Lewi, P. J.; Heeres, J.; de Jonge, M R.; Koymans, L. M. H.; Vinkers, H. M.; Daeyaert, F.; Ludovici, D. W.; Kukla, M. J.; De Corte, B.; Kavash, R. W.; Ho, C. Y.; Ye, H.; Lichtenstein, M. A.; Andries, K.; Pauwels, R.; de Bethune, M.-P.; Boyer, P. L. Clark, P.; Hughes, S. H.; Janssen, P. A. J. Arnold, E. Roles of Conformational and Positional Adaptability in Structure-Based Design of TMC125-R165335 (Etravirine) and Related Nonnucleoside Reverse Transcriptase Inhibitors That Are Highly Potent and Effective against Wild-Type and Drug-Resistant HIV-1 Variants. J. Med. Chem. 2004, 47, 25502560

(19) (a) Cubero, E.; Luque, J. F.; Orozco, M. Is polarization important in cation- $\pi$ interactions? Proc Natl. Acad Sci. U.S.A 1998, 95 , 5976-5980. (b) Singh, J.; Thornton, J. M. SIRIUS. An automated method for the analysis of the preferred packing arrangements between protein groups. J. Mol. Biol. 1990, 211, 595-615. (c) Hunter, C. A.; Lawson, K. R.; Perkins, J.; Urch, C. J. Aromatic interactios, J. Chem. Soc., Perkin Trans. 2001, 2, 651-669. (d) Kim, K. S.; Tarakeshwar, P.; Yong Lee, J. Molecular clusters of $\pi$-Systems: Theoretical Studies of Structures, Spectra, and Origin of Interaction Energies. Chem. Rev. 2000, 100, 41454185

(20) De Clercq, E. Toward Improved Anti-HIV Chemotherapy: Therapeutic Strategies for Intervention with HIV Infections. J. Med. Chem. 1995, 38, 2491-2517.

(21) Dauber-Osguthorpe, P.; Roberts, V. A.; Osguthorpe, D. J.; Wolff J.; Genest, M.; Hagler, A. T. Structure and energetics of ligand binding to proteins: E. coli dihydrofolate reductasetrimethoprim, a drug-receptor system, Proteins: Struct., Funct. Genet. 1988, 4, 31-47.

(22) Fletcher, R. Unconstrained Optimization. In Pratical Methods of Optimization; John Wiley \& Sons: New York, 1980; Vol. 1.

(23) (a) Savini, L.; Gaeta, A.; Fattorusso, C.; Catalanotti, B.; Campiani, G.; Chiasserini, L.; Pellerano, C.; Novellino, E.; McKissic, D.; Saxena, A. Specific Targeting of Acetylcholinesterase and Butyrylcholinesterase Recognition Sites. Rational Design of Novel, Selective, and Highly Potent Cholinesterase Inhibitors. J. Med. Chem. 2003, 46, 1-4. (b) Fattorusso, C.; Butini, S.; Gaeta, A.; Agnusdei, M.; Gemma, S.; Persico, M.; Catalanotti, B.; Campiani, G.; Savini, L.; Nacci, V.; Novellino, E.; Holloway, H. W.; Greig, N.; McKissic, D.; Saxena. A.; Specific Targeting of Extra Interaction Sites (Mid-Gorge and Peripheral) in Butyrylcholinesterases (BuChEs) active site gorge. Rational Design of
Novel, Selective, and Highly Potent BuChE Inhibitors. J. Med. Chem. 2005 48, 1919-1929.

(24) Senderowitz, H.; Guarnieri, F.; Still, W. C. A Smart Monte Carlo Technique for Free Energy Simulations of Multiconformational Molecules. Direct Calculations of the Conformational Populations of Organic Molecules. J. Am. Chem. Soc. 1995, 117, 82118219 .

(25) Ding, H. Q.; Karasawa, N.; Goddard, W. A., III Atomic level simulations on a million particles: The cell multipole method for Coulomb and London nonbond interactions. J. Chem. Phys. 1992, 97, 4309-4315

(26) Maga, G.; Amacker, M.; Ruel, N.; Hubsher, U.; Spadari, S. Resistance to Nevirapine of HIV-1 Reverse Transcriptase Mutants: Loss of Stabilizing Interactions and Thermodynamic or Steric Barriers are Induced by Different Single Amino Acid Substitutions. J. Mol. Biol. 1997, 274, 738-747.

(27) Perno, C. F · Yarchoan, R.; Cooney, D A. Inhibition of Human Immunodeficiency Virus (HIV-1/HTLV-III-Ba-l) Replication in Fresh and Cultured Human Peripheral Blood Monocytes/Macrophages by Azidothymidine and Related 2',3'-Dideoxynucleosides. J. Exp. Med. 1988, 168, 1111-1125.

(28) Sodroski, J. G.; Rosen, C. A.; Haseltine, W. A. Trans-acting Transcriptional Activation of the Long Terminal Repeat of Human T Lymphotropic Viruses in Infected Cells. Science 1984, $225,381-385$

(29) Popovic, M.; Sarngadharen, M. G.; Read., E.; Gallo, R. C Detection, Isolation and Continuos Production of Cytopathic Retrovirus (HTLV-III) from Patients with AIDS and pre-AIDS. Science 1984, 224, 497-500.

(30) Gartner, S.; Markovits, P.; Markovitz, D. M.; Kaplan, M. H.; Gallo, R. C.; Popovic, M. The Role of Mononuclear Phagocytes in HTLV-III/LAV Infection. Science 1986, 233, 1533-1544.

(31) Karber, G.; Beitrag zur Kollektiven Behandlung Pharmakologischer Reihenversuche. Arch. Exp. Pharmakol. 1931, 162, 480483.

(32) Bergamini, A.; Perno, C. F.; Capozzi, M. A Tetrazolium-Based Colorimetric Assay for Quantification of HIV-1-Induced Cytopathogenicity in Monocyte-Macrophages Exposed to Macrophage- Colony Stimulating Factor. J. Virol. Methods 1992, 40, $275-286$.

(33) Pauwels, R.; Balzarini, J.; Baba, M. Rapid and Automated Tetrazolium Based Colorimetric Assay for the Detection of AntiHIV Compounds. J. Virol. Methods 1988, 20, 309-21.

(34) Campiani, G.; Fabbrini, M.; Morelli, E.; Nacci, V.; Greco, G.; Novellino, E.; Ramunno, A.; Maga, G.; Spadari, S.; Bergamini, A.; Faggioli, E.; Uccella, I.; Bolacchi, F.; Marini, S.; Coletta, M.; Fracasso, C.; Caccia, S. Non-Nucleoside HIV-1 Reverse Transcriptase Inhibitors: Synthesis and Biological Evaluation of Novel Quinoxalinylethylpyridylthioureas as Potent Antiviral Agents. Antivir. Chem. Chemother. 2000, 11, 141-155.

(35) Chou, T. C. Derivation and Properties of Micaelis-Menten Type and Hill Type Equations for Reference Ligands. J. Theor. Biol. 1976, 59, 253-276.

(36) Chou, T. C.; Talalay, I. Quantitative Analysis of Dose-Effect Relationships: the Combined Effects of Multiple Drugs or Enzyme Inhibitors. Adv. Enzyme Regul. 1984, 22, 27-55.

JM050257D 